\title{
Een cohortmodel voor RUBS
}

Citation for published version (APA):

Teunis, U. (1995). Een cohortmodel voor RUBS. Researchcentrum voor Onderwijs en Arbeidsmarkt, Faculteit der Economische Wetenschappen. ROA Working Papers No. 2

https://doi.org/10.26481/umarow.1995002

Document status and date:

Published: 01/01/1995

DOI:

10.26481/umarow.1995002

Document Version:

Publisher's PDF, also known as Version of record

\section{Please check the document version of this publication:}

- A submitted manuscript is the version of the article upon submission and before peer-review. There can be important differences between the submitted version and the official published version of record.

People interested in the research are advised to contact the author for the final version of the publication, or visit the DOI to the publisher's website.

- The final author version and the galley proof are versions of the publication after peer review.

- The final published version features the final layout of the paper including the volume, issue and page numbers.

Link to publication

\footnotetext{
General rights rights.

- You may freely distribute the URL identifying the publication in the public portal. please follow below link for the End User Agreement:

www.umlib.nl/taverne-license

Take down policy

If you believe that this document breaches copyright please contact us at:

repository@maastrichtuniversity.nl

providing details and we will investigate your claim.
}

Copyright and moral rights for the publications made accessible in the public portal are retained by the authors and/or other copyright owners and it is a condition of accessing publications that users recognise and abide by the legal requirements associated with these

- Users may download and print one copy of any publication from the public portal for the purpose of private study or research.

- You may not further distribute the material or use it for any profit-making activity or commercial gain

If the publication is distributed under the terms of Article $25 \mathrm{fa}$ of the Dutch Copyright Act, indicated by the "Taverne" license above, 
Een cohortmodel voor RUBS

U. Teunis

ROA-W-1995/2

Researchcentrum voor Onderwijs en Arbeidsmarkt

Faculteit der Economische Wetenschappen

Rijksuniversiteit Limburg

Maastricht, juli 1995 
CIP-GEGEVENS KONINKLIJKE BIBLIOTHEEK, DEN HAAG

Teunis, U.

Een cohortmodel voor RUBS / U. Teunis. - Maastricht : Researchcentrum voor Onderwijs en Arbeidsmarkt, Faculteit der Economische Wetenschappen, Rijksuniversiteit Limburg. (ROA-W-1995/2)

Met lit. opg.

ISBN 90-5321-159-4

Trefw.: informatiesystemen / onderwijs en arbeidsmarkt. 


\section{Inhoudsopgave}

Bladzijde

Inleiding

1 Noodzaak van verandering

2 Bestuurlijk en wettelijk kader

2.1 Veranderende wetgeving

11

2.2 Informatiestatuut, leerlingnummer

3 De informatiehuishouding in de praktijk $\quad 22$

3.1 De onderwijsinstellingen

23

3.2 De intermediaire organen

25

3.3 De landelijke overheid

27

4 Conclusies, aanbevelingen

Literatuur 



\section{Inleiding}

Dit rapport is het resultaat van een verkenning in opdracht van het ministerie van Onderwijs, Cultuur en Wetenschappen, directie Beroepsonderwijs en Volwassenen Educatie (BVE). Aanleiding tot deze verkenning was de constatering dat zich een aantal belangrijke nieuwe ontwikkelingen voordoen die voor het RUBS-project van belang zijn: het toenemend belang van leerlingvolgsystemen binnen de interne kwaliteitszorg van onderwijsinstellingen, het cohortmodel dat voor de jaarverslagen in de BVE-sector verplicht werd gesteld en het denken over een andere inrichting van de gegevenshuishouding tussen scholen en overheid. Samengevat luidde de vraagstelling de mogelijkheden te verkennen om het RUBS-onderzoek aan te doen sluiten op deze ontwikkelingen.

In het rapport wordt eerst nader ingegaan op deze ontwikkelingen en op ontwikkelingen binnen RUBS in verband hiermee (hoofdstuk 1). In hoofdstuk 2 wordt nader ingegaan op twee ontwikkelingen die in de nabije toekomst van groot belang zullen zijn: ten eerste het nieuwe wettelijk kader voor de BVE-sector als voorzien in het wetsvoorstel WEB en de nieuwe informatiebehoeften die daaruit voortvloeien; ten tweede de voornemens voor de toekomstige informatiehuishouding tussen onderwijsinstellingen en overheid (informatiestatuut, leerlingnummer). In hoofdstuk 3 wordt nader ingegaan op informatiehuishouding en de informatiebehoeften op school-, intermediair en overheidsniveau en de wijze waarop RUBS daarop in zou kunnen spelen. In hoofdstuk 4 tot slot wordt een aantal conclusies geformuleerd en worden aanbevelingen gedaan betreffende de toekomstige opzet van RUBS.

De verkenning concentreert zich op de sector BVE, maar waar van toepassing worden ook de implicaties voor de AVONWO-sector en het hoger onderwijs meegenomen; uitgangspunt is daarbij dat de 'scanners' op alle niveaus zoveel mogelijk volgens een zelfde model ingericht dienen te zijn.

De verkenning is in hoofdzaak uitgevoerd op basis van documentanalyse en gesprekken met een aantal betrokkenen. De documentanalyse had deels betrekking op interne documenten die niet in de literatuurlijst zijn vermeld. De gesprekken hadden deels het karakter van interviews, deels van overleg met partijen die direct bij RUBS zijn betrokken. De gesprekken hebben plaatsgevonden met vertegenwoordigers van de landelijke overheid c.q. de opdrachtgever en met een aantal respondenten vanuit onderwijsinstellingen en intermediaire organisaties. In eerstgenoemde gesprekken stonden de landelijke ontwikkelingen met betrekking tot de wetgeving, het informatiestatuut en het leerlingnummer centraal, in laatstgenoemden de ontwikkelingen in de administratie, de informatiehuishouding en de informatiebehoeften. De gesprekken waren gestructureerd aan de hand van een aantal globale gesprekspunten. Binnen de beperkte ruimte van een 
verkenning was het niet mogelijk tot een representatief overzicht van ontwikkelingen en informatiebehoeften bij onderwijsinstellingen en intermediaire organen te komen. Wel is, in combinatie met het schriftelijk materiaal, een goede indruk verkregen.

Gesprekken hebben plaatsgehad met (tijdsvolgorderlijk):

* dhr. L.J.J. Verhaegen, ministerie van OC \& W, directie BVE;

* dhr. J. Groos, ministerie van OC \& W, directie B\&B;

* mevr. I Lokman, STOAS, bureau arbeidsmarktonderzoek;

* mevr. L.J.M. Venema-Hobert, Technisch Lyceum Eindhoven, secretaris centrale directie;

* dhr. H. Rutjes, DESAN marktonderzoek;

* dhr. P. Klaassen, LDC;

* dhr. M.L.V. Babeliowsky, Sco;

* dhr. R. van Heezik, Zadkine college Rotterdam (telefonisch);

* dhr. G. van Weelden, gebruikersgroep CMG (telefonisch);

* mevr. G.C. De Vos-Brussee, centrale directie Zadkine college Rotterdam (telefonisch);

* dhr. H. Haring, SOM opleidingen metaal, afd. onderzoek en beleidsadviezen (telefonisch);

* dhr. P. Westmeijer, CIBB afd. onderzoek en advies (telefonisch);

* dhr. J. Bakker, Damland college te Zaandam (telefonisch).

Uitspraken van geïnterviewden zijn niet op naam herkenbaar in dit rapport opgenomen. Waar van toepassing wordt naar mondelinge informatie verwezen als 'mededeling in interview'.

\section{Noodzaak van verandering}

\section{RUBS in ontwikkeling}

RUBS (Registratie van Uitstroom en Bestemming Schoolverlaters) is in beweging. De bestuurlijke constructie rond dit grootschalige onderzoek, de organisatorische en logistieke vormgeving, de methodologische uitwerking en de wijze van rapportage aan de scholen en andere betrokkenen hebben de afgelopen jaren meer of minder ingrijpende veranderingen ondergaan. Toch is de kern van RUBS sinds haar ontstaan in 1987 onveranderd gebleven: het gaat om een enquête, afgenomen bij een grote groep -oudleerlingen die ongeveer 8 maanden tevoren een opleiding voor VBO, MAVO, HAVO, VWO, MBO of BBO hebben verlaten, betreffende hun huidige positie in vervolgonderwijs danwel de beroepsbevolking en de voorbereiding op die positie in het voorgaand onderwijs.

In al die tijd is RUBS ook altijd meer geweest dan 'registratie': het ging en gaat niet primair om het opbouwen van een databestand over uitstroom en bestemming maar om 
het genereren van relevante informatie voor de deelnemende scholen, voor regionale ondersteuningsorganisaties en voor landelijke betrokkenen.

RUBS is ontstaan uit een initiatief uit de kring van de toenmalige COA's, de Contactcentra onderwijs-arbeid. Het oorspronkelijke doel is daarmee gegeven: het opleveren van deugdelijke informatie met het oog op een betere onderbouwing van studie- en beroepskeuzevoorlichting. Tot en met RUBS 1994 speelden de (onder diverse namen opererende) Adviesbureaus voor Opleiding en Beroep AOB, waarin de COA's zijn opgegaan, een belangrijke rol in RUBS, met name in het contact met de scholen. Ingaande RUBS 1995 is deze rol goeddeels geëindigd, maar de AOB's blijven een belangrijke gebruikersgroep van RUBS-uitkomsten. Naast de AOB's speelt ook het Landelijk Dienstverlenend Centrum LDC een belangrijke rol in de sfeer van het projectmanagement en de vertaling van de RUBS-uitkomsten naar producten ten behoeve van de studie- en beroepskeuzevoorlichting. Deze rol zal worden voortgezet met een grotere nadruk op de landelijke productontwikkeling.

In de loop der jaren zijn wel andere doelen en functies van RUBS meer naar voren getreden: informatie met het oog op beleidsvorming en evaluatie op schoolniveau (vooral evaluatie van het extern effect van het onderwijsaanbod), informatie ten behoeve van het regionale arbeidsmarktbeleid, informatie ten behoeve van het landelijk arbeidsmarktbeleid en ten behoeve van beleidsvorming en evaluatie op het brede terrein van onderwijs, arbeidsmarkt en de overgangen daartussen. Ook is RUBS steeds meer gaan functioneren als database voor secundaire analyses in ander onderzoek.

\section{Veranderde omgeving}

Niet alleen RUBS is veranderd, ook de omgeving waarin het onderzoek wordt afgenomen is veranderd, en zal de komende jaren in hoog tempo verder veranderen. Een paar trends die zich aftekenen zijn:

* schaalvergroting en verzelfstandiging in het onderwijs: grotere scholen met steeds meer een regionale in plaats van locale oriëntatie; grotere nadruk op het zelfsturend vermogen van scholen binnen globale landelijke regels;

* professionalisering in het beheer en bestuur van deze grotere onderwijseenheden; meer systematische verzameling en verwerking van informatie als voorwaarde voor goed management;

* meer beleidsmatige nadruk op intern en extern rendement als strategische informatie voor de beleidsbepaling op schoolniveau; verschuiving van regelgeving van 'input' naar 'resultaat';

* toename van de technische mogelijkheden voor onderzoek op schoolniveau of in aansluiting op de administratieve gegevensverwerking van de school. Uit de literatuur en de gesprekken blijken wel grote verschillen tussen de scholen in het feitelijk benutten van deze mogelijkheden. 
In lijn met deze ontwikkelingen hebben zich vooral op het terrein van het beroepsonderwijs en de volwasseneneducatie verstrekkende veranderingen voorgedaan in de wet- en regelgeving betreffende het informatieverkeer tussen onderwijsinstellingen en overheid. Met de inwerkingtreding van de SVM-wet, de WCBO en de wet VAVO is een ontwikkeling gestart naar een informatieverkeer volgens het uitgangspunt: minder informatie ten behoeve van besluitvorming op input-niveau (toekenning van middelen, goedkeuringsprocedures e.d.), meer informatie ten behoeve van verantwoording achteraf en ten behoeve van landelijke evaluatie en beleidsvorming. Deze ontwikkeling is met genoemde wetten overigens niet afgesloten; zij kunnen eerder worden gezien als tussenstations op een weg die met het wetsvoorstel Educatie en Beroepsonderwijs (WEB) wordt voortgezet (voor een nadere analyse van het wettelijk kader zie hoofdstuk 2).

Binnen de thans geldende wetgeving is vooral het jaarverslag van belang. In dit openbaar verslag dient de school (voor MBO, CBE en VAVO) ondermeer inzicht te geven in de in-, door- en uitstroom van leerlingen. De gegevens worden gerapporteerd op cohort-basis: van iedere 'instroomgeneratie', de leerlingen die in een bepaald schooljaar aan een opleiding binnen de school beginnen, dient jaarlijks de status in termen van vertraging, verandering van opleiding en tenslotte uitstroom te worden vermeld. $\mathrm{Er}$ is geen verplichting tot vermelding van de bestemming van de uitgestroomde leerlingen, maar er is wel een aanbeveling in deze richting aan de scholen gedaan. Het jaarverslag heeft zowel functies voor de school (interne evaluatie, verantwoording aan en relaties met de onmiddellijke omgeving) als voor de overheid (informatievoorziening voor inspectietoezicht en landelijke evaluatie).

In het wetsvoorstel WEB (inmiddels door de Tweede Kamer aanvaard) wordt deze lijn verder doorgetrokken. De combinatie van functies in het jaarverslag wordt losgelaten. De interne evaluatie en de verantwoording richting de omgeving worden aan de instelling gelaten (maar er komt wel een wettelijke verplichting om een systeem van interne kwaliteitszorg in te richten); de informatieverstrekking aan de Rijksoverheid wordt zoveel mogelijk gegoten in de vorm van een databestand op individueel (leerling-) niveau, van waaruit de overheid zelve informatie voor haar diverse informatiebehoeften dient te genereren.

Ook deze vorm van informatieuitwisseling bevat niet het element van bestemming van de uitgestroomde leerlingen. Diverse onderdelen van de voorziene Wet impliceren echter de noodzaak informatie over de arbeidsmarkt en de aansluiting tussen onderwijs en arbeidsmarkt te verzamelen en te verwerken. Die noodzaak ontstaat op instellingsniveau, op intermediair niveau (landelijke organen beroepsonderwijs) en op overheidsniveau (zie verder hoofdstuk 2). In het wetsvoorstel wordt de wijze waarop deze informatie zal worden verzameld echter niet aangegeven. 
In de 'omgeving van RUBS' verandert niet alleen het denken over de relatie tussen overheid en scholen en het informatieverkeer in verband daarmee; ook de technische voorwaarden voor onderzoek en informatieverkeer veranderen. De techniek is daarbij geen neutraal aspect: de veranderde opvattingen over het informatieverkeer hebben alles te maken met de veranderde technische mogelijkheden. De ontwikkeling is grofweg van schriftelijke overdracht van geaggregeerde gegevens op formulier, via overdracht van geaggregeerde bestanden op electronische gegevensdrager (diskette), naar overdracht van individuele gegevens op leerlingniveau langs electronische weg ('on line' via het zgn. BVE-net). De aloude overdracht van gegevens op formulier hield verband met de geldende bestuurlijke verhoudingen (gegevens vooraf voor sturing op input-niveau, b.v. de leerlingtelling t.b.v. de bekostiging), maar ook met de technische mogelijkheden om gegevens te verwerken. Deze vorm van gegevensoverdracht past niet meer in de zich ontwikkelende bestuurlijke verhoudingen, maar is bovendien vanuit de huidige technische mogelijkheden inefficiënt geworden. Zowel efficiëntie als nieuwe bestuurlijke verhoudingen wijzen nu naar gebruik van de 'electronische snelweg' en naar gegevensoverdracht op zo laag mogelijk aggregatieniveau.

Binnen de thans geldende wet- en regelgeving bevindt het informatieverkeer zich in een overgangsfase: nog overwegend op bestandsniveau, maar wel meestal met behulp van electronische gegevensdragers. Zowel de telgegevens als de integrale bestanden in het kader van het jaarverslag worden overwegend op diskette aangeboden. Het integrale jaarverslag-bestand is, hoewel geagregeerd op opleidingsniveau, naar instroomgeneraties geordend. De electronische aanlevering maakt de opbouw van een landelijk bestand mogelijk waarop nadere analyses kunnen worden uitgevoerd betreffende het rendement van het bestel als geheel.

$\mathrm{Na}$ inwerkingtreding van de WEB zal de overstap worden gemaakt naar informatieoverdracht 'on line' en naar overdracht van gegevens gekoppeld aan individuele leerlingen met behulp van een leerlingnummer. Er zijn vergaande plannen tot invoering van een landelijk leerlingnummer voor het hele onderwijsbestel, waarbij de BVE-sector voorop zal Iopen (zie verder hoofdstuk 2). Als leerlingnummer zal waarschijnlijk het SoFi-nummer worden gebruikt. Dat betekent dat, binnen grenzen in verband met o.m. de privacybescherming, leerlingen in principe kunnen worden gevolgd in hun leerweg door de successieve schoolsoorten en zelfs in hun carrière na uitstroom uit het onderwijs. Dat kan vergaande gevolgen hebben voor het cohort- en bestemmingsonderzoek, zoals dat thans steeksproefgewijze wordt uitgevoerd.

De ontwikkelingen in het gegevensverkeer worden mede mogelijk gemaakt door (maar worden in de praktijk ook ontworpen met het oog op) de automatisering van de administratieve systemen binnen de instellingen. Vrijwel alle BVE-instellingen gebruiken 
thans één van de grotere administratieve pakketten: in het MBO overwegend 'schoolfact' van CMG, in het VAVO SAVE-III, in het CBO LEAD van (voorheen) Victor Holland of SAVE-III. Deze pakketten maken allen met zekere beperkingen het genereren en bewerken van individuele leerlinggegevens ten behoeve van onderzoek en evaluatie op school- en landelijk niveau mogelijk. Van deze mogelijkheid is gebruik gemaakt bij de implementatie van de jaarverslagregeling MBO; met subsidie van het ministerie zijn toen bij de meest gebruikelijke pakketten modulen geschreven voor het genereren van de jaarverslag-gegevens op cohort-basis. In de praktijk gaat het opleveren van gegevens boven het niveau van de directe administratieve noodzaak overigens nog met veel problemen gepaard (mededelingen in interviews). Met het oog op de informatiehuishouding zoals voorzien in de WEB bereiden een aantal software-bedrijven thans in samenwerking een pakket voor het hele BVE-veld voor, NOISE, dat nog beter op de gegevensverwerking en -levering op individueel niveau zal zijn toegesneden.

\section{Gevolgen voor RUBS}

In aansluiting op de hierboven gesignaleerde ontwikkelingen werden in het onderzoeksvoorstel voor het project 'een cohort-model voor RUBS' van maart 1994 de volgende mogelijke knelpunten gesignaleerd:

1. RUBS geeft een momentopname, gebaseerd op enquêtering van een steekproef uitgestroomde leerlingen. Het design is transversaal, niet longitudinaal. De zich ontwikkelende systemen voor zowel de interne kwaliteitszorg binnen de instellingen als de gegevensuitwisseling met de overheid gaan echter uit van een longitudinaal model, gebaseerd op een leerlingvolgsysteem.

2. Ook de jaarverslag-regelingen (thans $\mathrm{MBO}$, binnenkort ook $\mathrm{CBO}$ ) gaan uit van een longitudinaal model op basis van instroomgeneraties (cohorten). RUBS, gebaseerd op een steekproef uit uitstroom-cohorten, sluit hier niet bij aan.

3. RUBS sluit dus ook niet aan bij ontwikkelingen in de automatisering van de leerlingenadministratie, die uitgaan van een leerlingvolgsysteem en verslaglegging op cohortbasis.

4. Hetzelfde geldt voor de beoogde andere opzet van landelijke tellingen en statistische informatievoorziening, eveneens gebaseerd op individuele leerlinggegevens die landelijk worden geanalyseerd ten behoeve van de gebruiksdoelen op dat niveau.

Deze inventarisatie van knelpunten, die begin vorig jaar werd geformuleerd, dient op een aantal punten te worden genuanceerd. RUBS is flexibel genoeg gebleken om op een aantal van deze knelpunten in te spelen. Ten eerste wordt ingaande 1994 standaard aan MBO-scholen het vrijwillige kengetal betreffende de bestemming van uitgestroomde leerlingen (kengetal E) aangeleverd. Dit is mogelijk aangezien de startdatum in de opleiding van waaruit de leerling is uitgestroomd aan de respondent wordt gevraagd. Op basis van dit gegeven kunnen retrospectief instroomcohorten worden gereconstrueerd. Hieraan zijn wel beperkingen verbonden, ten eerste door de foutmarge die altijd bij 
retrospectieve constructies ontstaat, ten tweede omdat de instroomcohorten zoals gedefinieerd door de jaarverslag-regeling niet volledig kunnen worden gereconstrueerd (met overstap van de ene naar de andere opleiding binnen de zelfde school en met tussentijdse instroom vanuit een andere $\mathrm{MBO}-$ school kan geen rekening worden gehouden).

Ten tweede vindt terugmelding van de RUBS-uitkomsten aan de school plaats in een aantal vormen, waaronder een database op individueel niveau. Hierin worden alleen die respondenten opgenomen die op het vragenformulier te kennen hebben gegeven geen bezwaar tegen terugmelding aan de school te hebben. Zij worden in de database opgenomen op naam en op volgnummer binnen de onderzoeksgroep. Desgewenst kan de school hier het leerlingnummer uit de eigen administratie aan toevoegen, waarna verdere analyses mogelijk zijn.

Ten derde worden MBO-scholen in de gelegenheid gesteld zelf leerlingnummers aan te reiken die worden toegevoegd aan de individuele gegevens in genoemd terugmeldingsbestand (opnieuw onder voorwaarde van instemming van de respondent). Door middel van deze zgn. koppelnummers kan de school de RUBS-uitkomsten automatisch in het leerlingvolgsysteem opnemen. In RUBS 1994 hebben twee MBO-scholen van deze mogelijkheid gebruik gemaakt, zij het echter in hoofdzaak met het oog op efficiëntie (gemakkelijker aanlevering van de adresgegevens); van de mogelijkheid tot analyse door koppeling aan de gegevens in het leerlingvolgsysteem is nog geen gebruik gemaakt (mededelingen in interviews).

Recente ontwikkelingen binnen RUBS

Andere ontwikkelingen, die in maart 1994 nog niet of niet ten volle konden worden voorzien zijn:

1. De ontwikkeling van het leerlingnummer: de concretisering van het al langer bestaande idee is in een stroomversnelling geraakt; er zijn nu betrekkelijk concrete plannen tot inrichting van het gegevensverkeer tussen scholen en overheid op basis van leerlingnummers; de sector BVE zal daarbij voorop lopen (zie verder hoofdstuk 2). Dat betekent dat plannen voor aansluiting tussen RUBS en leerlingnummer nu verder kunnen worden uitgewerkt.

2. Ontwikkeling longitudinale opzet van RUBS: deze houdt verband met het zgn. integratieproject RUBS - SVS. Het Schoolverlaters Volg Systeem SVS is een initiatief van de Nederlandse Vereniging van Schooldecanen. Naar Deens model is een betrekkelijk eenvoudige vragenlijst ontworpen, waarmee uitgestroomde MAVO- en VBO-leerlingen vier keer in twee schooljaren worden benaderd. Het doel hiervan is niet wetenschappelijk (er vindt geen landelijke vergelijking plaats) maar praktisch: enige feedback ten behoeve van de school, maar vooral de mogelijkheid voor de decaan oud-leerlingen, die aangeven in 
het vervolgonderwijs moeilijkheden te ondervinden, enige ondersteuning te bieden. De lijst wordt daarom door de school verzonden en na respons verwerkt, zodat snelle reactie mogelijk is.

Hoewel de doelen deels verschillend zijn overlapt de vragenlijst qua inhoud sterk met RUBS. Er wordt thans een project uitgevoerd in samenwerking tussen NVS, LDC en ROA tot integratie van beide projecten. Uitgangspunt is daarbij dat de RUBS-enquête één van de vier bevragingen van het SVS vervangt, waarbij de sterke kanten van beide systemen behouden blijven. Deze integratie van RUBS in een reeks bevragingen kan de aanzet zijn tot een meer longitudinale opzet, waarbij de ontwikkeling van de loopbaan na uitstroom aan de hand van meerdere opeenvolgende metingen kan worden gevolgd. Binnen het integratieproject beperkt deze longitudinale opzet zich tot de deelnemende school en tot uitstromers uit MAVO en VBO, maar uitbreiding naar andere vormen van onderwijs en naar meer onderzoeksdoelen is denkbaar.

3. Ontwikkeling specifieke bevragingen: scholen voor AVONWO hebben gesignaleerd dat de huidige RUBS-vragenlijst te sterk is toegesneden op de positie op de arbeidsmarkt en te weinig informatie biedt over oud-leerlingen in het vervolgonderwijs. Aangezien de directe aansluiting op de arbeidsmarkt vanuit MAVO, HAVO en WWO erg gering is geworden beperkt dit de functionaliteit van RUBS. Op het moment wordt een nieuwe vragenlijst ontworpen voor het AVONWO en VBO. Uitgangspunt is een meer flexibele opzet van RUBS, waarbij naast een aantal basisvragen modulen kunnen worden toegevoegd naar gelang de specifieke behoeften van scholen en onderwijstypen.

4. Veranderde steekproeftrekking: er hebben zich de afgelopen jaren aanzienlijke wijzigingen voorgedaan in de wijze waarop scholen, en daarbinnen onderwijstypen of opleidingen, in RUBS worden opgenomen. Deze veranderingen hangen samen met de wijze waarop RUBS wordt georganiseerd en gefinancierd. De details van deze ontwikkeling vallen buiten het kader van dit onderzoek. Het effect is echter wel van belang: van een situatie waarin de meeste scholen deelnamen als entiteit binnen een grote landelijke steekproef (waarbij het initiatief dus niet bij de school lag en het belang voor de school een afgeleide was) ontstaat nu een situatie waarin RUBS steeds meer afhankelijk is van de vrijwillige deelname van de scholen. Belangrijke implicatie is dat de functionaliteit van RUBS voor de deelnemende scholen eerder dient te worden uitgebouwd dan beperkt; iedere verandering van design dient hiermee rekening te houden.

5. Toenemende service: RUBS heeft in het verleden nogal wat werk met zich meegebracht voor de deelnemende scholen. Zij moesten zelf zorgdragen voor verzending van de vragenlijsten aan de respondenten, voor het rappel en voor de doorzending van de terugontvangen lijsten voor centrale verwerking. Deze hoeveelheid werk was één van de redenen waarom in bepaalde gevallen besloten is niet meer aan RUBS deel te nemen 
(mededeling in interview). Bovendien bleek niet iedere school in staat dit werk volledig uit te voeren: met name de verzendadministratie en het rappel vertoonden gebreken. Thans wordt aan de scholen de mogelijkheid geboden van centrale verzending en verwerking op basis van een aangeleverd adressenbestand. Hiervan maakt inmiddels zo'n $80 \%$ van de deelnemende scholen gebruik. De drempel voor deelname is hiermee aanzienlijk verlaagd.

Overigens toont dit gegeven een zekere spanning waarmee rekening moet worden gehouden bij design-veranderingen: enerzijds is er behoefte aan schoolspecifieke aanpassingen en aan snelle terugkoppeling met het oog op specifieke schooldoelen (studie- en beroepskeuzevoorlichting, decanaat e.d.), anderzijds komen veel scholen niet toe aan het werk dat hiervoor noodzakelijk is en besteden zij een deel van dit werk gaarne uit. Ontwikkelingen als het landelijk leerlingnummer bieden hiervoor nieuwe mogelijkheden. De spanning tussen schoolnabijheid, service aan de school en landelijke functies en mogelijkheden zal echter veel aandacht moeten krijgen.

\section{Uitwerking vraagstelling}

De oorspronkelijke vraagstelling in het onderzoeksvoorstel van maart 1994 luidde "een exploratie, en zo mogelijk ontwikkeling, van mogelijkheden om RUBS op termijn op een andere leest te schoeien. Kort samengevat: van een herhaalde transversale (bestands-) meting naar een meting die tevens longitudinale analyses op basis van cohorten toestaat". Binnen deze vraagstelling werden twee deelprojecten onderscheiden: aansluiting op korte termijn op het cohort-model van het jaarverslag in de BVE-sector en verkenning van verdere mogelijkheden op grond van ontwikkelingen in het informatieverkeer tussen scholen en overheid.

Zoals boven aangegeven hebben latere ontwikkelingen deze vraagstelling gedeeltelijk ingehaald. Enerzijds is de aansluiting op het cohortmodel binnen zekere beperkingen tot stand gebracht (oplevering kengetal E) en zijn andere ontwikkelingen gaande (longitudinaal model, flexibele/modulaire opzet, meer service), anderzijds gaat de ontwikkeling van het leerlingnummer nu zeer snel. Een hernieuwde overweging van de vraagstelling is dus nodig.

Daarvoor dient vooreerst te worden overwogen wat van de oorspronkelijke vraagstelling nog niet als gevolg van lopende ontwikkelingen wordt gerealiseerd. In hoofdlijn gaat het dan om twee punten:

1. Analyses bij schoolloopbaan: de thans geleverde retrospectieve cohortanalyse is beperkt tot het vereiste van kengetal $\mathrm{E}$, nl. de positie na uitstroom per instroomgeneratie naar opleiding en geslacht (met enige beperkingen: zie boven). Wat nog niet binnen RUBS mogelijk is een analyse waarbij instroomkenmerken, kenmerken van de schoolloopbaan, behaald resultaat en positie in de vervolgsituatie systematisch met elkaar in 
verband worden gebracht volgens een longitudinaal model. Scholen worden nu alleen in staat gesteld deze analyses zelf uit te voeren (d.m.v. de zgn. koppelnummers). Dergelijke modellen zijn op zich beschikbaar als gevolg van eerder cohortonderzoek.

2. Efficiënt gebruik van het leerlingnummer: het ligt voor de hand het leerlingnummer te gebruiken in het kader van RUBS. Daarvoor zijn verschillende alternatieven voorhanden, van vergaande (landelijke steekproeftrekking) tot meer beperkte (b.v. gebruik voor een meerjarig volgen van de respondenten).

Bij het ontwerpen van nieuwe modellen dient rekening te worden gehouden met een aantal randvoorwaarden en criteria:

* Multifunctionaliteit: RUBS heeft functies op schoolniveau, op intermediair niveau en op landelijk niveau. Deze multifunctionaliteit dient te worden behouden.

* Bruikbaarheid op schoolniveau: vooral op schoolniveau lijkt thans niet alles uit RUBS te worden gehaald wat er potentieel inzit. Van de specifieke meerwaarde van RUBS ten opzichte van vergelijkbare projecten (landelijke vergelijking, mogelijkheid van terugkoppeling naar het leerlingvolgsysteem) lijkt lang niet in alle gevallen optimaal gebruik te worden gemaakt. Nieuwe modellen dienen dit te bevorderen, waarbij dient te worden aangesloten bij de -heel verschillende- mogelijkheden van de scholen op de korte en wat langere termijn.

* Uitbreiding bereik: RUBS zal steeds meer drijven op de vrijwillige deelname van scholen. Nieuwe modellen dienen bij te dragen aan een groter bereik onder de scholen, door betere service en uitbreiding van de gebruiksmogelijkheden.

* Functies in het WEB-stelsel: de beoogde WEB impliceert een toenemend belang van informatie over de arbeidsmarkt en de aansluiting onderwijs-arbeidsmarkt op diverse niveaus (zie hoofdstuk 2). Vooral in verband met het opbouwen en onderhouden van de zgn. landelijke kwalificatiestructuur ontstaan nieuwe functies voor dit type informatie; de landelijke organen beroepsonderwijs treden naar voren als potentiële doelgroep. Op deze nieuwe behoeften en functies moet worden ingespeeld.

* Beperkt financieel kader: de landelijk gegarandeerde middelen voor RUBS zullen in volume beperkt blijven. De vrijwillige deelname door scholen en intermediaire organen wordt ook in financieel opzicht relatief belangrijker. Onder die voorwaarden moet voorzichtig worden omgegaan met modellen die tot structureel hogere kosten zouden leiden.

Gezien de ontwikkelingen van de laatste jaren en genoemde randvoorwaarden en criteria (en gezien de beperkte omvang van deze verkenning) zou de vraagstelling thans kunnen luiden:

1. het verkennen van de mogelijkheden voor een RUBS-model dat longitudinale analyses op basis van entree-kenmerken, schoolloopbaangegevens en vervolgposities mogelijk maakt,

2. met optimaal gebruik van de mogelijkheden van het landelijk leerlingnummer,

3. dat aansluit op de behoeften en gebruiksmogelijkheden op school-, intermediair en 
landelijk niveau,

4. met bijzondere aandacht voor de nieuwe gebruiksmogelijkheden op intermediair niveau binnen het WEB-stelsel,

5. en dat past binnen het huidige budgettair kader en anticipeert op een toenemend belang van vrijwillige deelname van scholen en intermediaire organen;

6. het formuleren van de uitgangspunten voor het ontwerpen en implementeren van zo'n model.

\section{Bestuurlijk en wettelijk kader}

\subsection{Veranderende wetgeving}

Bestuurlijke uitgangspunten, algemeen

De integratie van gegevens over het extern rendement (uitstroom en bestemming) en het intern rendement (resultaat in relatie tot instroom) past in de grotere nadruk op externe verantwoording en oriëntatie op de omgeving, die reeds een aantal jaren de kern van het onderwijsbeleid vormt. Achtergrond is ten eerste het streven naar afstandelijkheid van bestuur, waarbij de overheid terugtreedt op het vlak van voorschriften voor inrichting en examen, doch nadere voorschriften geeft ten aanzien van de te bereiken resultaten (eindtermen, landelijke kwalificatiestructuur), verslaglegging en verantwoording van de bereikte resultaten. Ten tweede is er een, moeilijker in eenduidige begrippen te vatten, toename van de oriëntatie op de externe effecten van het onderwijs, niet alleen aan de kant van de overheid maar ook binnen het onderwijsveld en onder de leerlingen. Onderwijsinstellingen, zeker die op het terrein van het beroepsonderwijs, ontwikkelen steeds meer een bedrijfsmatig en professioneel zelfbegrip, waarbij het leveren van een goed 'product' en gerichtheid op de behoeften van de 'klant' steeds vanzelfsprekender oriëntatiepunten zijn. De arbeidsmarkt en het succes van de oud-leerlingen daarop wordt van randvoorwaarde tot uiteindelijk doel. Ook de leerlingen lijken zich meer op de arbeidsmarkt te richten. Studiekeuzes vinden "nuchter, zakelijk en zelfbewust" plaats, waarbij de kans op een baan als keuzecriterium qua gewicht op het niveau is gekomen van de eigen interesses en capaciteiten (Vincken, 1994).

De vertaling van deze trends en uitgangspunten in het wettelijk kader en het feitelijk functioneren van het beroepsonderwijs is minder eenduidig. Een aantal zaken zijn vastgelegd in de 'eerste generatie' specifieke BVE-wetten, de thans geldende SVM-wet en de WCBO, die in ontwerp uit de tweede helft van de jaren '80 stammen. In de 'tweede generatie', het thans voorliggende wetsvoorstel WEB, worden een aantal lijnen verder doorgetrokken. 
Tot de inwerkingtreding, per augustus 1991, van de zgn. SVM-wet (Sectorvorming en Vernieuwing Middelbaar beroepsonderwijs) van mei 1990 was het MBO geregeld krachtens de Wet voortgezet onderwijs (WVO) en volgens de zelfde systematiek als het overig voortgezet onderwijs. Dat betekende de vaststelling van inrichtings- en examenbesluiten per vorm van MBO. De inrichtingsbesluiten bevatten een aantal, weliswaar globale, inrichtingsvoorschriften, waaronder in de meeste gevallen een minimumlessentabel en voorschriften omtrent duur en inrichting van de stages. Ook de examenbesluiten volgden de AVO-systematiek, met verdeling in centraal examen en schoolonderzoek en examenprogramma's per vak (er waren overigens aanzienlijke verschillen in uitwerking per vorm van $\mathrm{MBO}$ ). Buiten de examenprogramma's werden geen expliciete wettelijke eisen gesteld aan het resultaat. Uiteraard was de werkelijkheid genuanceerder dan in deze korte typering naar voren komt (enerzijds waren de inrichtings- en examenvoorschriften, inclusief de examenprogramma's, in grote lijnen tamelijk globaal; anderzijds waren er diverse terugkoppelingsmechanismen vanuit de arbeidswerkelijkheid, waaronder de examenprogramma- en examencommissies, schoolcontacten met bedrijven, inspectietoezicht e.a.). Toch kan de MBO-wetgeving tot 1991 worden gekarakteriseerd als input-gericht in plaats van resultaatgericht. De Wet bevatte geen expliciete verwijzing naar te bereiken resultaten, laat staan naar de arbeidsmarkt.

Weliswaar is de SVM-wet een wijzigingswet binnen de WWO, maar de systematiek is op hoofdpunten fundamenteel anders. De reikwijdte van de inrichtingsvoorschriften wordt sterk beperkt; een minimumlessentabel is niet meer mogelijk. Ook voor de inrichting van het examen worden slechts beperkte voorschriften gegeven. Het centraal examen verdwijnt in de meeste gevallen; alleen bepaalde onderdelen (certificaateenheden) zullen centraal worden geëxamineerd.

Daartegenover staat de introductie van de eindtermen als definitie van het te bereiken resultaat. Deze dienen een beschrijving te geven van "kwaliteiten van leerlingen op het gebied van kennis, inzicht, vaardigheden en beroepshoudingen'. De eindtermen worden geclusterd tot certificaateenheden met een 'afzonderlijke betekenis .... in het licht van de beroepsuitoefening of de doorstroming naar vervolgonderwijs" (art. 17 lid 2). De eindtermen worden vastgesteld door de minister "op gezamenlijk voorstel van organisaties uit onderwijs en bedrijfsleven die door Onze minister als representatief zijn aangemerkt" (art. 17 lid 1). Thans fungeren als zodanig de landelijke organen beroepsonderwijs. De school dient de eindtermen te vertalen in eigen onderwijs- en vormingsdoelen, zij dient in een schoolwerkplan aan te geven hoe deze zullen worden bereikt en zij dient "op grondslag van de vastgestelde eindtermen" het examenprogramma vast te stellen, waarbij de certificaateenheden de examenonderdelen vormen; alleen voor de centraal te examineren onderdelen stelt de minister het programma vast (art. 17a, 24a en 29a). 
Laatste principiële wijziging is de introductie van het jaarverslag. Dit is een jaarlijks openbaar verslag, toe te zenden aan de inspectie. De introductie van het jaarverslag wordt nadrukkelijk in verband gebracht met de overgang van inrichtingsvoorschriften vooraf naar resultaatbepaling en verantwoording achteraf.

Per augustus 1993 verving de Wet cursorisch beroepsonderwijs (WCBO) van mei 1992 ondermeer de Wet op het leerlingwezen en de inrichtingsvoorschriften omtrent het BBO. Anders dan het MBO onder het regime van de WVO bevatte de Wet op het leerlingwezen wel nadrukkelijk bepalingen aangaande de gerichtheid op de arbeidsmarkt. Belangrijkste daarvan waren de instellingen van de landelijke organen leerlingwezen en de verantwoordelijkheden van deze landelijke organen voor de 'totaalprogramma's' (gecombineerde leerplannen en examenprogramma's per opleiding) en de opleiding in de praktijk van het beroep.

Verschillende van deze elementen zijn gehandhaafd in de WCBO, maar de systematiek van de wet volgt op hoofdpunten die van de SVM-wet. Ook hier vinden we de eindtermen, het schoolwerkplan, het examenprogramma en het jaarverslag. Zeer wezenlijk is dat krachtens de WCBO dezelfde Landelijke Organen Beroepsonderwijs verantwoordelijk zijn gesteld voor de ontwikkeling van eindtermen voor MBO en leerlingwezen; de afstemming tussen de eindtermen van beide typen onderwijs is een wettelijke opdracht. Zo werd de wettelijke grondslag gelegd voor de ontwikkeling van een landelijke kwalificatiestructuur voor het hele secundair beroepsonderwijs.

\section{De jaarverslagregeling}

De SVM-wet en de WCBO bepalen dat voor twee van de vier onderdelen van het jaarverslag nadere voorschriften zullen worden gegeven: het overzicht van de verzorgde opleidingen en het overzicht van in-, door- en uitstroom van leerlingen. Deze bepaling vormde de grondslag voor de 'Regeling jaarverslag MBO' van juni 1991 (gewijzigd in juli 1992); een regeling voor het jaarverslag WCBO wordt binnenkort verwacht. Voor de twee andere onderdelen, algemene gang van zaken en contractactiviteiten, biedt de Wet geen grond voor nadere voorschriften; in de toelichting bij de regeling worden wel enige vrijblijvende aanwijzingen gegeven.

De toelichting bij de regeling jaarverslag MBO noemt vier functies van het jaarverslag:

1. het verslag aan de inspectie, met het oog op wettelijk toezicht en bevordering van de kwaliteit;

2. grondslag voor een landelijk beeld van de kwaliteit van het MBO, o.m. ten behoeve van het verslag aan de Staten-Generaal;

3. openbare verantwoording door de school aan haar omgeving, in het bijzonder ouders en leerlingen en het bedrijfsleven;

4. interne evaluatie van de kwaliteit, in het bijzonder aan de hand van de rendements- 
cijfers.

Kern van de voorschriften voor het jaarverslag vormt het overzicht van in-, door- en uitstroom van de leerlingen. Dit overzicht krijgt de vorm van een aantal verplichte kengetallen en (met ingang van de gewijzigde regeling) een zgn. integraal overzicht. Er is nadrukkelijk voor gekozen door middel van deze kengetallen het (interne) rendement van de scholen, en daarbinnen dat van de onderscheiden opleidingen, in beeld te brengen. Daarom dienen de kengetallen per cohort (instroomgeneratie) te worden berekend. Alle leerlingen die in een schooljaar met enige opleiding beginnen vormen de instroomgeneratie. Hiervan worden de kenmerken vastgesteld (kengetallen instroom), worden vertraging en verandering van opleiding binnen de school weergegeven (kengetallen doorstroom) en worden het resultaat en het uiteindelijke rendement bepaald, gerelateerd aan de vooropleiding en de verblijfsduur (kengetallen uitstroom).

In de kengetallen worden, overeenkomstig de bepaling in de Wet, de leerlingen onderscheiden naar geslacht en vooropleiding. De toelichting bij de regeling stelt daarnaast twee vrijwillige uitbreidingen voor: één naar allochtone achtergrond en één naar bestemming na uitstroom. Dit laatste, kengetal e, zou gebaseerd dienen te zijn op bevraging van de uitgestroomde leerlingen na 10 maanden. De gegevens dienen te worden weergegeven per instroomgeneratie, onderscheiden naar uitstroomresultaat (diploma danwel één/meer certificaten), geslacht en bestemming (vervolgopleiding, werk en geen werk/werkzoekend). Aangezien leerlingen van één vervolgopleiding op verschillende momenten uitstromen wordt als alternatief een weergave per uitstroomgeneratie genoemd. Daarmee wordt, ook door de termijn van 10 maanden, het gebruik van RUBS-uitkomsten voor kengetal e mogelijk.

De jaarverslagbepaling in de SVM-wet en de daarop gebaseerde regeling jaarverslag MBO kunnen met een gerust hart revolutionair worden genoemd. Niet eerder was een schoolsoort verplicht in openbaarheid systematisch over kwaliteit en uitkomsten te rapporteren en daarbij ook het (interne) rendement zichtbaar te maken. Dat neemt niet weg dat de invoering met veel moeilijkheden gepaard is gegaan en dat het de scholen nog steeds veel moeite kost de kengetallen volledig en betrouwbaar ingevuld te krijgen. Beperkingen in de gebruikelijke administratieve programma's zijn daar mede debet aan (mededeling in interview).

Naast uitvoeringsproblemen brengt de jaarverslagregeling in haar huidige vorm een aantal structurele beperkingen met zich mee. Een belangrijke beperking vormt de aanlevering op geaggregeerd niveau in de vorm van tabellen. Met name als gevolg van vertraging en vooral wisseling van opleiding zijn de kengetallen beperkt interpreteerbaar (bij verandering van opleiding wordt de leerling toegerekend naar de instroomgeneratie van de nieuwe opleiding. Het analyseren van leertrajecten is op deze wijze niet mogelijk). Op landelijk niveau kunnen slechts beperkt analyses worden uitgevoerd op het bestand dat de 
inspectie op basis van de afzonderlijke verslagen opbouwt, dit nog los van het gegeven dat de opgaven bij lange na niet volledig zijn.

Een alternatief voor de aanlevering in de vorm van tabellen zou die in de vorm van (evt. geanonimiseerde) leerlinggegevens zijn, naast samenvatting in kengetallen in het openbaar verslag. Dit alternatief is bij de ontwikkeling van de jaarverslag-regeling MBO wel overwogen, maar uiteindelijk niet gekozen. Het landbouwonderwijs had de informatieuitwisseling tussen overheid (het ministerie van LNV) en scholen reeds een aantal jaren tevoren naar dit model ingericht. Alle landelijke informatiebehoefte (ook ten behoeve van bekostiging, statistiek en toezicht) wordt hier gevoed uit een integraal leerlingenbestand dat de scholen jaarlijks aan het ministerie doorgeven. Bij de ontwikkeling van de jaarverslagregelingen WCBO en VAVO is opnieuw gepoogd individuele leerlinggegevens als grondslag te nemen, mede in aansluiting op ontwikkelingen in het kader van het zgn. informatiestatuut en het wetsvoorstel WEB (zie hieronder). De uiteindelijke keuzes op dit punt zijn echter nog niet zeker.

\section{Het wetsvoorstel WEB}

Het voorstel van wet Educatie en Beroepsonderwijs is thans in behandeling bij de Tweede Kamer. Het wetsvoorstel beoogt integratie van beroeps- en volwassenenonderwijs (MBO, deeltijd-MBO, BBO/leerlingwezen, VAVO en basiseducatie) in één wettelijk kader; het MBO zou hiermee definitief loskomen van het overig voortgezet onderwijs. Materieel beoogt het voorstel vooral de concentratie van alle beroeps- en volwassenenonderwijs in ruim 50 Regionale Opleidingen Centra (ROC), waarbij overigens de mate van integratie kan variëren van een overwegend bestuurlijke fusie tot integratie op het niveau van organisatie en uitvoering van het onderwijs. Het proces van ROC-vorming is inmiddels in volle gang. Streven is naar inwerkingtreding van de Wet per 1 januari 1996, waarna geleidelijke invoering van de nieuwe structuur plaatsvindt.

Op het vlak van de oriëntatie op de omgeving en de verantwoording achteraf trekt het wetsvoorstel de lijnen door die in gang zijn gezet met de SVM-wet en de WCBO. In de laatste Nota van Wijziging is het wetsvoorstel juist op deze punten verder aangescherpt. In het navolgende wordt met 'wetsvoorstel' steeds het gewijzigde voorstel bedoeld.

In grote lijnen ongewijzigd zijn de bepalingen aangaande de eindtermen en deelkwalificaties (certificaateenheden in de SVM-wet en WCBO). De landelijke organen behouden hun taakstelling ten dezen. Het voorstel plaatst deze taakstelling nadrukkelijk in het licht van een 'landelijke kwalificatiestructuur', die de eindtermen volgens een vast stramien in een horizontale structuur (opleidingen) en een verticale structuur (niveaus) onderbrengt. De landelijke organen dienen deze landelijke kwalificatiestructuur te ontwikkelen en te onderhouden, "gericht op de aansluiting tussen het aanbod van beroepsonderwijs en de maatschappelijke behoeften daaraan, mede in het licht van de arbeidsmarktperspectieven 
van afgestudeerden". De eindtermen worden, op advies van de landelijke organen, vastgesteld door de minister (art. 1.5 .2 resp. 7.2.4). Wat betreft het examen vervalt het examenprogramma als extern te toetsen vertaling van de eindtermen. In plaats daarvan kunnen de landelijke organen een deel van de deelkwalificaties aanwijzen voor 'externe legitimering'; deze dient te geschieden door of vanwege een 'exameninstelling'. De vormgeving van deze externe legitimering is verder niet bepaald. Als exameninstelling kunnen de landelijke organen optreden, maar b.v. ook particuliere instellingen.

Naast de bepaling van het te bereiken resultaat in de eindtermen ontbreken inrichtingsvoorschriften vrijwel geheel. De ROC's krijgen ook, anders dan binnen de huidige wetgeving, een grote mate van vrijheid in de bepaling van het eigen onderwijsaanbod. De minister bepaalt jaarlijks welke opleidingen voor bekostiging in aanmerking komen, en wel op basis van maatschappelijke behoeften, de arbeidsmarktperspectieven van afgestudeerden en de bijdrage van de opleiding aan een duurzame en brede beroepskwalificatie (art. 2.1.1). Het bevoegd gezag is vervolgens vrij te bepalen welke opleidingen uit dit bekostigd aanbod de school feitelijk zal verzorgen. $\mathrm{Er}$ is wel een toetsing achteraf op deze keuze mogelijk. De minister kan bepaalde opleidingen rechten onthouden, "indien de verzorging van de opleiding kennelijk niet doelmatig kan worden geacht" (art. 6.1.1 resp. 6.1.3).

Het wraken van een voorgenomen opleiding geschiedt op advies van een nieuw in te stellen 'Adviescommissie onderwijs-arbeidsmarkt'. Leden van deze commissie zullen worden voorgedragen door de landelijke organen, werkgevers- en werknemersorganisaties en de instellingen, naast leden benoemd door de minister. Deze commissie krijgt twee taken: ten eerste dient zij de landelijke organen te adviseren over de concept-eindtermen, vooral in het perspectief van het tot stand komen van een landelijke kwalificatiestructuur; ten tweede beoordeelt zij de doelmatigheid van de beroepsopleidingen die de instellingen voornemens zijn te verzorgen. Blijkbaar wordt deze commissie vooral een rol toegedacht in het bewaken van de samenhang binnen het stelsel in relatie tot vooral de arbeidsmarkt, zowel vooraf (samenhang tussen de eindtermen-voorstellen) als achteraf (toetsing opleidingenaanbod).

Wat betreft de kwaliteitszorg komt eveneens de nadruk te liggen op toetsing en verantwoording achteraf. Het bevoegd gezag wordt verplicht een "stelsel van kwaliteitszorg" in te richten en te voorzien in een "regelmatige beoordeling van de kwaliteit van het onderwijs .... met betrokkenheid van onafhankelijke deskundigen" (art. 1.3.6). De inspectie krijgt de nadrukkelijke opdracht toe te zien op dit stelsel van kwaliteitszorg; daarmee krijgt het toezicht deels het karakter van 'meta-evaluatie'. Voor het jaarverslag wordt slechts bepaald dat dit er moet zijn en dat het openbaar is; er kunnen geen nadere voorschriften meer worden gegeven voor de inhoud ervan. Daartegenover staat dat een afzonderlijke wettelijke regeling van het informatieverkeer tussen instellingen en overheid mogelijk wordt. Er kunnen voorschriften worden gegeven omtrent de beschikbaarstelling van 
administratieve gegevens van de instelling; de instellingen dienen in relatie tot de bekostiging medewerking te verlenen aan onderzoek op basis van deze gegevens. Daarnaast kan worden bepaald dat de Minister een bijdrage in de kosten van het verzamelen en verstrekken van bepaalde gegevens verschuldigd is (art. 2.6.3 resp. 2.6.5). Deze wettelijke grondslag voor het informatieverkeer wordt beargumenteerd in de 'Nota naar aanleiding van het Eindverslag', waarop de eerdergenoemde Nota van Wijziging is gebaseerd. Uitgangspunt is dat het informatieverkeer zoveel mogelijk zal worden ingevuld op basis van afspraken met het onderwijsveld in het zgn. informatiestatuut, waarbij de (nog in te vullen) bekostigingsregels een dwingend kader vormen. Er worden vijf hoofdstromen van informatie onderscheiden: bekostigingsinformatie, financiële verslaglegging, het kwaliteitsverslag (de weerslag van het stelsel van kwaliteitszorg), de beleidsinformatie en het jaarverslag.

Uitgangspunt is het multifunctioneel gebruik van door de scholen te leveren gegevens, waardoor het Rijk voor zijn onderscheiden gebruiksdoelen in principe met één gegevenslevering toe kan. Het onderscheid tussen bekostigingsgegevens en beleidsinformatie is formeel, niet inhoudelijk: de eersten zijn op basis van de bekostigingsregels verplichtend; de beleidsinformatie daarentegen wordt na overleg met het veld vastgesteld, terwijl de minister een vergoeding verschuldigd kan zijn (zie boven). Inhoudelijk gaat het echter om één stroom gegevens, waarbij de gedachten uitgaan naar individuele leerlinggegevens op basis van een onderwijsnummer.

Over het informatiestatuut vindt reeds enige tijd overleg plaats tussen veld en overheid. De uitgangspunten, zoals die verwoord zijn in de Nota naar aanleiding van het Eindverslag, lijken ook in dit overleg te zijn aanvaard. Aan de voorbereiding van invoering van het onderwijsnummer wordt serieus gewerkt (zie verder paragraaf 2.2).

\section{Gevolgen voor uitstroom- en arbeidsmarktinformatie}

Het wetsvoorstel WEB en het onderliggend proces van invulling van de informatiehuishouding in overleg met het onderwijsveld zullen vergaande consequenties hebben voor onderzoek naar de bestemming van uitgestroomde leerlingen en de arbeidsmarktpositie van categorieën gediplomeerden. Deze consequenties liggen zowel op het vlak van het 'aanbod' van informatie (de beschikbaarheid van gegevens, de technische voorwaarden) als op het vlak van de 'vraag'.

Wat betreft het 'aanbod': hier gaat het om de nieuwe inrichting van de informatieuitwisseling tussen instellingen en overheid, de levering van individuele gegevens op leerlingnummer en het uitgangspunt van multifunctioneel gebruik. Hier wordt verder op ingegaan in paragraaf 2.2 .

Wat betreft de 'vraag': het wetsvoorstel bepaalt op een aantal punten expressis verbis het 
gebruik van gegevens over de arbeidsmarkt-posities en de maatschappelijke vraag; op andere punten behoort dit gebruik tot de logische bedoeling. Hieruit vloeit een vraag naar informatie voort op landelijk, 'intermediair' en instellingsniveau.

Op het landelijk niveau, i.c. de Rijksoverheid, dient de minister het aanbod van beroepsopleidingen vast te stellen op basis van o.m. "de maatschappelijke behoeften ..., mede in het licht van het onderwijsaanbod verzorgd door niet ... bekostigde instellingen" en "de arbeidsmarktperspectieven van de afgestudeerden" (art. 2.1.1). Verder dient de minister de eindtermen vast te stellen "met het oog op de totstandkoming van een landelijke kwalificatiestructuur, gericht op de aansluiting tussen het aanbod van beroepsonderwijs en de maatschappelijke behoeften daaraan, mede in het licht van de arbeidsmarktperspectieven voor afgestudeerden" (art. 7.2.4). Samenvattend betekent dit dat de minister de vaststelling van zowel de opleidingen als de door die opleidingen te bereiken leereffecten primair op maatschappelijke behoeften en verwachte vraag op de arbeidsmarkt dient te bepalen.

Op intermediair niveau fungeren vooral de landelijke organen en de adviescommissie onderwijs-arbeidsmarkt. De landelijke organen dienen de landelijke kwalificatiestructuur te ontwikkelen en te onderhouden, "gericht op aansluiting tussen het aanbod van beroepsonderwijs en de maatschappelijke behoeften daaraan, mede in het licht van de arbeidsmarktperspectieven voor afgestudeerden" (art. 1.5.2). In concreto houdt dit in dat de landelijke organen een voorstel voor de vaststelling van eindtermen en de indeling daarvan in deelkwalificaties aan de minister voorleggen ter vaststelling. Aan te nemen is dat de toetsing op maatschappelijke behoeften en arbeidsmarkt-vraag, die de minister bij deze vaststelling moet uitvoeren, voor een aanzienlijk deel op de inbreng van de landelijke organen zal steunen.

De adviescommissie heeft de twee eerdergenoemde taken van advisering over de concept-eindtermen en beoordeling van de doelmatigheid van het voorgenomen opleidingenaanbod van de instellingen. Hoewel dat niet expliciet wordt aangegeven is, ook gezien de naamgeving en samenstelling van de commissie, aan te nemen dat arbeidsmarkt-verwachtingen bij deze advisering en toetsing een rol zullen spelen.

De instellingen tot slot krijgen tot taak het verzorgen van educatie en beroepsonderwijs, waarbij zij mede zorg dienen te dragen voor "het bieden van mogelijkheden voor studiekeuze- en beroepskeuzevoorlichting" en voor "afstemming op de ontwikkelingen in de samenleving op nationaal en internationaal gebied in het algemeen en ten aanzien van de arbeidsmarkt in het bijzonder" (art. 1.3.5). De instelling dient verder een stelsel van kwaliteitszorg op te zetten en bij de regelmatige beoordeling van de kwaliteit onafhankelijke deskundigen te betrekken (art. 1.3.6). Zij dient een openbaar jaarverslag uit te brengen en zij dient mee te werken aan gegevensverstrekking aan de Rijksoverheid. Bij de 'hoofdstromen van informatie', waarop deze gegevensverstrekking moet worden 
gebaseerd (Nota naar aanleiding van het Eindverslag), worden gegevens over de bestemming van uitgestroomde leerlingen evenwel niet expliciet genoemd.

Los van deze in het wetsvoorstel onderscheiden taken van de instellingen is het de bedoeling dat de instellingen, de ROC's, in het WEB-stelsel zullen fungeren als grote, in hoge mate zelfstandige en professioneel geleide organisaties met een sterke oriëntatie op en openheid naar de regionale arbeidsmarkt. Het ontwikkelen van regionaal overleg, gericht op afspraken met de arbeidsmarkt-partijen in de regio, wordt van groot belang geacht (Beleidsagenda EB). Er zullen voortdurend contacten met bedrijven nodig zijn, o.m. met het oog op het verwerven van voldoende praktijkleerplaatsen. De inhaerente spanning tussen de beoogde "toegankelijkheid van het onderwijs, in het bijzonder voor kansarme groepen" (art. 1.3.5), het streven naar rendementverhoging en de noodzaak te voldoen aan de kwantitatieve en kwalitatieve vereisten van de arbeidsmarkt noopt tot een voortdurende bewaking van de effectiviteit en het intern en extern rendement. Deze combinatie van doelstellingen en vereisten maakt een zeer goede geïnformeerdheid noodzakelijk, vooral op het niveau van het management en het middle-management, betreffende de regionale arbeidsmarkt en de prestaties van de oud-leerlingen op die arbeidsmarkt.

Algemene conclusie kan zijn dat het WEB-stelsel een toenemende vraag met zich mee zal brengen naar systematische en betrouwbare informatie over de maatschappelijke vraag, en in het bijzonder de vraag op de arbeidsmarkt, naar specifieke opleidingen c.q. typen gekwalificeerden en over de effecten van het onderwijs op de arbeidsmarkt. Deze vraag is niet vrijblijvend: zonder deze systematische en betrouwbare informatie zijn essentiële onderdelen van de WEB op drijfzand gebouwd, of anders gezegd: kunnen essentiële adviesfuncties en cruciale beleidsbeslissingen zowel inhoudelijk als in termen van rechtszekerheid niet voldoende worden onderbouwd. De vraag naar informatie is er op alle betrokken niveaus, maar het meest pregnant lijkt zij toch op het intermediaire niveau van de landelijke organen en de adviescommissie en op instellingsniveau. De vraag betreft dus informatie op twee aggregatieniveaus: landelijk/sectoraal (gekoppeld aan de branche-indeling van de landelijke organen) en regionaal.

Waar het specifiek gaat om informatie die voortkomt uit analyses volgens cohortmodel, waarbij verbanden worden gelegd tussen instroomkenmerken, schoolloopbanen, uitstroomkenmerken en bestemming na uitstroom, lijkt de behoefte gezien het beoogde wettelijke stelsel vooral te liggen bij de instellingen en op het landelijke niveau.

Op instellingsniveau kan deze informatie een belangrijke functie vervullen in het kader van de interne kwaliteitszorg, als één van de informatiebronnen betreffende het effect van specifieke opleidingen en van specifieke inrichtingsvormen. In het bijzonder is deze informatie van belang voor het doelgroepenbeleid: de onderwijskansen van specifieke doelgroepen binnen de instelling kunnen worden bewaakt niet alleen in termen van uiteindelijk resultaat maar ook in termen van verschillen in leerweg; ook kunnen oorzaken 
van problemen worden opgespoord (wie loopt vast en waar gaat het fout?). Daarnaast is er het minder aan een cohortmodel gebonden gebruik als informatiebron betreffende arbeidsmarkteffecten en arbeidsmarktvraag.

Op landelijk niveau kunnen vragen worden gesteld aangaande de effectiviteit en de efficiëntie van het stelsel. Ook hier zou de effectiviteit van het doelgroepenbeleid een belangrijk thema kunnen zijn. Vragen op dit niveau kunnen worden beantwoord met behulp van de 'klassieke' methodologie van het cohortonderzoek.

\subsection{Informatiestatuut, leerlingnummer}

De idee van een informatiestatuut is ouder dan het wetsvoorstel WEB. Reeds enige jaren is het beleidsmatig uitgangspunt dat de gegevenslevering tussen instellingen en overheid een steviger basis behoeft dan tot dan gebruikelijk. Daarbij waren zowel belangen van de overheid als van de onderwijsinstellingen in het geding. Binnen het 'klassieke' wettelijke stelsel kon de overheid in hoofdlijn beschikken over twee typen gegevensstromen betreffende functioneren en rendement van het onderwijsbestel: telgegevens die hun grondslag hadden in de wettelijke voorwaarden tot bekostiging (ook de CBS-statistiek was en deels is voor een groot deel gebaseerd op deze telgegevens) en speciaal aanbesteed onderzoek. Deze gegevensbasis is op verschillende wijzen aangetast. Andere systemen van kwaliteitsbepaling en bekostiging (zie boven) leiden tot een aanzienlijke reductie van de stroom telgegevens; onderzoek kost veel additioneel geld en is sterk afhankelijk van de medewerking van de scholen. De zekerstelling van een voldoende informatievoorziening voor evaluatie en beleidsvorming kwam zo in het geding.

Voor de onderwijsinstellingen waren er andere belangen in het geding. De klassieke overdracht van telgegevens op formulier en later ook op diskette bracht en brengt veel administratieve last met zich mee. Die last werd als zwaarder ervaren naar mate de evidente noodzaak in het kader van de bekostiging minder werd ervaren. Verzelfstandigde onderwijsinstellingen zetten eerder vraagtekens bij de noodzaak van de gegevensvraag vanuit de overheid. Veel bezwaar was en is er ook tegen regelmatige verandering van de gegevensvraag vanuit de overheid. Naarmate de instellingen voor hun administratie afhankelijker werden van door software-bedrijven geleverde programmatuur werd dit als meer bezwaarlijk gezien. Lang niet alle instellingen hebben de deskundigheid in huis om zelf applicaties op hun software te maken met het oog op specifieke informatiebehoeften, intern en extern. Onderzoek wordt als een grote belasting ervaren. Scholen worden doodgegooid met verzoeken om medewerking aan alle mogelijke soorten onderzoek; onderzoek door of vanwege de overheid is hier slechts een deel van.

In dat complex van problemen en belangen kwam het idee naar voren een afsprakenstelsel tussen overheid en instellingen te ontwikkelen als kader voor de informatieuitwisseling. Uitgangspunten waren daarbij transparantie (een expliciete en 
onderbouwde informatiebehoefte als grondslag voor gegevensvraag), stabiliteit (vastgelegde perioden waarin de vastgestelde gegevensvraag niet mag worden gewijzigd) en wederkerigheid (vastlegging van zowel de gegevensvraag van de overheid als de informatievoorziening aan de instellingen). Dit afsprakenstelsel zou moeten worden vastgelegd in een informatiestatuut, een convenant op het specifieke terrein van de informatievoorziening.

Tot een informatiestatuut in deze zin is het niet gekomen. Naast praktische waren er ook juridische problemen, waaronder de ook uit de thans geldende 'generatie' BVE-wetgeving voortvloeiende gegevensvraag. Het denken over en het overleg in het kader van het informatiestatuut is wel van groot belang geweest voor het formuleren van de informatiehuishouding, zoals die nu in het kader van het wetsvoorstel WEB is voorzien. In dit stelsel wordt het uitgangspunt vastgelegd dat de minister de vraag naar beleidsinformatie, die uitgaat boven de gegevensvraag met het oog op de bekostiging, vaststelt na overleg met het veld en voor een bepaalde afgesproken periode; dit geschiede in het informatiestatuut. Principes zijn daarbij multifunctionaliteit (één stroom van gegevens voor de verschillende gebruiksdoelen, vermindering administratieve belasting), wederkerigheid (basisgegevens in ruil voor bewerking en vergelijkingsmateriaal), transparantie (explicitering van definities en gebruiksdoelen) en versterking van de juridische basis (wetgeving, informatiestatuut) (informatieplan BVE 1995).

Met het oog op deze explicitering wordt gewerkt aan een zgn. gegevenswoordenboek. Dit gaat uit van de levering van gegevens op individueel niveau (leerlinggegevens op nummer). Alle gegevens die aan dit nummer zullen worden gehangen worden hierin afzonderlijk gedefinieerd, zowel inhoudelijk als in informatietechnische zin. Met behulp van dit gegevenswoordenboek dienen scholen hun (geautomatiseerde) administratie te kunnen inrichten op de actuele gegevensvraag tegen minimale administratieve last en kosten.

\section{Leerlingnummer}

De idee dat de gegevensuitwisseling tussen onderwijsinstellingen en overheid efficiënter kan worden ingericht door gebruikmaking van een leelingnummer bestaat al langer. $\mathrm{Er}$ waren echter ook veel bezwaren tegen, zowel in de sfeer van de technisch-administratieve voorwaarden als op het vlak van de privacy-bescherming en de angst voor de overheid als 'big brother'. Een aantal ontwikkelingen heeft echter de aanvaarding van het leerlingnummer in een stroomversnelling gebracht:

* het denken in termen van een informatiestatuut, waarbij de informatie- uitwisseling niet als eenzijdig verplichtend doch als wederkerig en op afspraak wordt gezien;

* het streven naar vermindering van de administratieve last door uit te gaan van multifunctionele basale gegevens;

* de beperkingen in de huidige voorziening in beleidsinformatie; zo bleek in het debat 
over de 'omwegen' in het onderwijsbestel dat het met de huidige matrixstatistiek (gebaseerd op mutaties tussen jaarbestanden) niet mogelijk is hier echt een vinger achter te krijgen;

* de bezuinigen op het budget van het CBS, die zowel de matrixstatistiek als het cohortonderzoek in gevaar hebben gebracht;

* de toenemende beleidsmatige aandacht voor leerlingen die zonder voldoende kwalificatie het onderwijs verlaten (streven naar startkwalificaties); dit heeft een grotere aandacht voor individuele trajectbewaking en -begeleiding met zich meegebracht;

* de opneming van het Sociaal-Fiscaal nummer (SoFi-nummer) in de Gemeentelijke Basis Administratie GBA, waardoor een in alle onderwijstypen bruikbaar nummer beschikbaar kwam.

Inmiddels is het streven naar een leerlingnummer aanvaard door de ambtelijke en politieke 'top' van het ministerie van OC \& W. Als leerlingnummer is het SoFi-nummer gekozen. Streven is naar invoering in alle vormen van onderwijs per augustus 1997. Voor wat betreft de BVE-sector is het streven naar invoering per augustus 1996 . Er is een afzonderlijke wettelijke regeling nodig voor invoering van het leerlingnummer. Voor de BVE-sector kan de regeling op basis van de WEB (beoogde datum van inwerkingtreding januari 1996) de grondslag vormen; voor de andere schoolsoorten zal een wetsvoorstel moeten worden voorgelegd. Er zijn, mede in verband met de technische complicaties van de overgang naar een administratie op basis van leerlingnummers, wel vraagtekens gezet bij de haalbaarheid van invoering in 1997.

\section{De informatiehuishouding in de praktijk}

In het voorgaande is gekeken naar de informatiebehoefte die voortkomt en voort zal komen uit het zich ontwikkelend wettelijk systeem en de taken en functies die daarbinnen worden belegd. Ook is gesignaleerd dat de ontwikkelingen op technisch gebied een aantal mogelijkheden openen die ook een vraag naar benutting daarvan kunnen oproepen. Daarmee is nog niets gezegd over de feitelijke informatiebehoefte, zoals die zich binnen de onderwijsinstellingen, relevante intermediaire organen en de overheid ontwikkelt. Er kan op dit vlak een forse kloof gapen tussen 'theorie' en 'praktijk', al is het alleen maar door de tijd die organisaties nodig hebben om op nieuwe mogelijkheden enerzijds en nieuwe externe vereisten anderzijds in te spelen.

Door documentanalyse en door middel van de gevoerde gesprekken is getracht hier een beeld van te krijgen. Zoals in de inleiding aangegeven is het aantal gevoerde gesprekken te gering om in te kunnen staan voor de representativiteit; het ging om een globale indruk. Aangezien de verschillende respondenten echter in hoge mate consistent zijn in hun uitspraken lijkt deze globale indruk toch betrekkelijk betrouwbaar. In het navolgende wordt 
afzonderlijk ingegaan op de onderwijsinstellingen, enige intermediaire organisaties (landelijke organen, STOAS en LDC) en de landelijke overheid.

\subsection{De onderwijsinstellingen}

Het algemene beeld dat naar voren komt waar het gaat om de onderwijsinstellingen binnen de sector BVE is die van een behoorlijke kloof tussen de praktijk van de informatiehuishouding enerzijds en de gestelde doelen en de manifeste verwachtingen, ook die binnen de instellingen zelve, anderzijds. Met deze kloof dient ter dege rekening te worden gehouden bij het ontwerpen van nieuwe informatiesystemen die een beroep doen op de informatiehuishouding van de scholen.

De kloof tussen theorie en praktijk lijkt met een drietal typen factoren samen te hangen: de informatievraag binnen de instellingen, administratief-technische problemen en de overgang van 'oude' naar 'nieuwe' informatiebronnen. Achter al deze factoren steekt echter een gemeenschappelijke: de zeer snelle ontwikkeling die het BVE-veld de afgelopen jaren heeft doorgemaakt, zowel institutioneel (fusies, schaalvergroting) als qua doelstellingen en onderwijsinhouden. Meerdere respondenten geven aan dat de informatiehuishouding deze ontwikkelingen niet heeft kunnen bijhouden; ook veel technische en organisatorische problemen hangen met de feitelijkheid van een overgangssituatie samen. Aangezien met de voorziene inwerkingtreding van de WEB per 1 januari 1996 een volgende ronde van institutionele herschikking en inhoudelijke heroriëntatie wordt ingegaan is niet te verwachten dat deze situatie op korte termijn essentieel zal veranderen. Respondenten verwachten dat, net zoals bij de eerdere ronde, de SVM-operatie, de institutionele en personele problemen een groot deel van de beschikbare energie zullen wegzuigen.

\section{De interne informatievraag}

De instellingen lijken zich nog sterk te oriënteren op de externe informatievraag: de leerlingtellingen, de vereisten van de jaarverslag-regeling. Intern blijkt de informatievraag, zoals die zou kunnen worden verwacht in relatie tot het zich ontwikkelend stelsel van kwaliteitszorg, het doelgroepenbeleid enz., nog weinig uitgewerkt. Verschillende respondenten gaven aan dat er van de kant van centrale directie nauwelijks een gerichte informatievraag komt. Ook de gegevens die in het kader van het jaarverslag moeten worden verzameld hebben niet in alle gevallen de voorziene functie van interne evaluatie. Initiatieven als nadere analyses op het leerlingvolgsysteem en relatering aan bestemmingsgegevens worden interessant gevonden, maar bij gebrek aan een vastgesteld informatiebeleid en gerichte belangstelling van de 'top' wordt er weinig in geïnvesteerd. 


\section{Administratieve en technische problemen}

Alle BVE-instellingen, voorzover bekend, maken gebruik van één van de grotere administratieve pakketten; 'schoolfact' van CMG is met 60 scholen de grootste. Deze pakketten hebben in potentie een grote capaciteit, zowel waar het gaat om het afhandelen van de administratieve verplichtingen als met het oog op intern-beleidsmatig gebruik (monitoring, evaluatie, specifieke analyses in relatie tot beleidsvragen). Nieuwe ontwikkelingen als een modulaire structuur zijn inpasbaar. Een meerjarig volgen van de leerlingen, met het oog op een leerlingvolgsysteem en cohortanalyses, is mogelijk. Ook het koppelen aan externe gegevens, b.v. RUBS-uitkomsten, is in principe mogelijk. In de praktijk blijkt het gebruik zich vooral op het administratieve vlak af te spelen. De instellingen ontmoeten daarbij nogal wat problemen. De pakketten worden te ingewikkeld genoemd; er is teveel scholing van het administratief personeel vereist. Bovendien staat en valt het gebruik met een goede gegevensinvoer en een goede interpretatie van uitvoer-categorieën (b.v. de begrippen 'vertraging', 'overgestapt' e.d. in de jaarverslagregeling); hier gaat echter nogal eens iets mis. Oorzaak is hier ook het gedrag van de leerlingen, die b.v. school verlaten, adreswijzigingen e.d. niet tijdig melden. Ook hier zijn de fusies een belangrijke oorzaak van problemen. Een deel van de instellingen werkt met meerdere niet communicerende pakketten, de erfenis van de fusiepartners. Andere instellingen hebben gekozen voor één pakket, maar moesten daardoor de gegevens van fusiepartners herinvoeren. In beide gevallen is er van een optimale informatiehuishouding geen sprake.

\section{Oude en nieuwe informatiebronnen}

Het type informatie waar het in deze verkenning om gaat, analyses op kwantitatieve gegevens volgens een min of meer wetenschappelijk model, is binnen de informatiehuishouding van onderwijsinstellingen betrekkelijk nieuw. Op het terrein waar het hier specifiek om gaat, de bestemming van schoolverlaters, arbeidsmarktkansen en de externe effecten van het onderwijs, had en heeft men zo zijn gegevens. In de praktijk lijkt hier nog steeds op te worden gevaren.

Wat betreft het BBO/leerlingwezen is er het gegeven dat de leerlingen reeds in de beroepspraktijk werkzaam zijn. Informatie komt hierdoor snel door. Wat betreft het MBO worden leerplan- en eindtermendocumenten genoemd als informatiebron. Verder zijn er contacten met het bedrijfsleven, zij het in meerdere danwel mindere mate gestructureerd en systematisch. Met uitgestroomde leerlingen wordt niet door alle scholen enig contact onderhouden. Eén respondent gaf aan dat alleen ongediplomeerde uitstromers onder KMBO-niveau worden benaderd voor trajectbegeleiding in samenwerking met het $A O B$, in het kader van het startkwalificatiebeleid. Het algemene beeld is dat er van een systematische omgevingsverkenning en een systematische verkenning van de externe effecten van het onderwijs nog geen sprake is. 


\section{Verdere ontwikkeling}

Meerdere respondenten gaven aan op het onderhavige terrein wel nieuwe ontwikkelingen en initiatieven te verwachten. Er wordt thans gewerkt aan een nieuw pakket voor de komende ROC's, NOISE, in samenwerking tussen alle grote software-leveranciers. Deze ontwikkeling kan een deel van de eerdere problemen voorkomen. Ook op het vlak van de informatievraag wordt een verdere ontwikkeling verwacht, waarbij o.m. de analyse op doelgroep werd genoemd. Eén respondent gaf aan dat cohortanalyses zullen worden uitgevoerd zodra de jaarverslag-cohorten het onderwijs beginnen te verlaten. Ook werd naar voren gebracht dat enige externe ondersteuning stimulerend zou kunnen werken. Zo zou definiëring van de informatiebehoefte kunnen worden gefaciliteerd door het gezamenlijk, in het kader van de Unie BVE, ontwikkelen van een aantal indicatoren ten behoeve van de kwaliteitszorg.

\subsection{De intermediaire organen}

De landelijke organen beroepsonderwijs

Op het punt van de landelijke organen beroepsonderwijs is de bevraging erg beperkt geweest. Uitspraken hierover dienen dus met de nodige voorzichtigheid te worden benaderd. De landelijke organen krijgen in het wetsvoorstel WEB een aantal taken die een gerichte informatievraag met zich mee kunnen brengen. Wat betreft het type informatie waar het hier om gaat zijn vooral de taken in het kader van de opbouw en het onderhoud van de landelijke kwalificatiestructuur van belang. Informatie over de prestaties van typen gediplomeerden op de arbeidsmarkt, gerelateerd aan de gevolgde opleiding, onderverdelingen daarbinnen (certificaten, modulen) en evt. leerweggegevens, kunnen in dat verband van groot belang zijn.

De indruk is dat de landelijke organen en hun ondersteunende structuren (CIBB, COLO) zich nog op deze situatie aan het instellen zijn. Systematisch onderzoek onder gediplomeerden van het leerlingwezen heeft nog niet op grotere schaal plaatsgevonden; RUBS heeft binnen het BBO nooit een groot bereik gehad (er is wel een aanzet tot dit type informatievoorziening; zie hieronder). Er wordt op gewezen dat het gegeven dat de leerlingen al een arbeidsplaats hebben een betrekkelijk directe informatie over de aansluiting impliceert. Anderzijds wordt gesteld dat de eerste functie na diplomering vaak nog niet op het niveau van de (voor)opleiding is, zodat de waarde van bestemmingsonderzoek zeker voor de kwalificatie-ontwikkeling beperkt is. Daarom wordt directe bevraging van de werkgevers betreffende de kwalificatievraag van meer belang geacht.

Het CIBB ontwikkelt in dat verband voor één van de landelijke organen een monitoringsysteem ter signalering van ontwikkelingen binnen de betreffende bedrijfstak. Dit is 
gebaseerd op regelmatige bevraging van een netwerk van deskundigen binnen de bedrijven, gevolgd door toetsing via een steekproef uit de bedrijven. Het gaat daarbij vooral om veranderingen binnen functies en de daaruit resulterende veranderingen in de kwalificatievraag.

Overigens is, in samenwerking met twee andere landelijke organen (SOBB -brood en banket- en SVO -vleessector-), ook een cursistenmonitor ontwikkeld, gebaseerd op meerdere gegevens in verband met de cursisten. Deze moet vanaf augustus 1995 operationeel zijn (CIBB, 1995). Als doelen worden o.m. monitoring van de deelname, rendementsverbetering en de meting van het effect van wijzigingen in de inrichting genoemd. over het feitelijk gebruik van deze monitor is nu nog weinig bekend.

\section{STOAS}

STOAS is een ondersteuningsinstelling ten behoeve van het agrarisch onderwijs met een zeer brede taakstelling, waaronder de lerarenopleiding, taken in verband met de landelijke kwalificatiestructuur en onderzoek en informatievoorziening. Sinds enige jaren is aan STOAS een afzonderlijk bureau arbeidsmarktonderzoek verbonden. De informatiehuishouding binnen het agrarisch onderwijs is anders ingericht dan in het overig beroepsonderwijs. Het departement van LNV, tevens inspectie, onderhoudt een landelijke gegevensbank, gebaseerd op de administratie van de afzonderlijke scholen; de bank wordt gevoed met basale gegevens op leerlingniveau. Op basis van deze gegevens worden een aantal indicatoren betreffende de kwaliteit van het onderwijs, waaronder de kengetallen voor het jaarverslag, centraal aangemaakt. Onderzoek naar de bestemming van schoolverlaters vindt intensief plaats. Abituriënten van het hoger agrarisch onderwijs worden zelfs tot en met hun pensionering gevolgd. Voor wat betreft het middelbaar agrarisch onderwijs is het streven om het jaar een compleet uitstroomcohort 15 jaar lang te volgen, waarbij de respondenten in die 15 jaar vijf keer worden bevraagd. Eén van deze bevragingen valt samen met een RUBS-bevraging. Een nadere analyse van verbanden tussen bestemmings- en schoolloopbaangegevens vindt thans nog niet plaats. Wel is thans een project in uitvoering tot ontwikkeling van een aantal indicatoren voor de meting van het intern rendement van de afzonderlijke scholen (Lokman, 1994). Mogelijk zal dit type analyses in dat kader van belang kunnen worden.

\section{$\angle D C$}

Het Landelijk Dienstverlenend Centrum LDC heeft ondermeer een belangrijke taak in het ondersteunen van de studie- en beroepskeuzevoorlichting op school- en regionaal niveau. In dat verband is het LDC een belangrijke afnemer van RUBS-gegevens, naast en in het verlengde van zijn coördinerende rol in de uitvoering van dit onderzoek. Op basis van (ondermeer) RUBS-uitkomsten wordt een aantal informatieproducten aangeboden, gericht op intermediairs (decanen, voorlichters van de RDC e.d.) en eindgebruikers (leerlingen, 
werkzoekenden e.d.): het boekje 'kansen op werk', de database 'traject', de serie 'beroep en werk' en sinds kort de serie 'de regionale arbeidsmarkt'. Voor de nabije toekomst is voorzien dat het LDC nog nadrukkelijker een taak krijgt in het ontwikkelen en aanbieden van informatieproducten op basis van RUBS, terwijl de uitvoeringscoördinatie meer aan de onderzoeker, i.c. het ROA, wordt overgedragen.

Door het LDC wordt binnenkort een rapport uitgebracht over leertrajecten in het voortgezet onderwijs. Op basis van de RUBS-gegevens heeft het ROA hiertoe de belangrijkste leerwegen in kaart gebracht. Dit is echter gebeurd op basis van de zogeheten 'synthetische' cohortmethode. Door de koppeling van RUBS aan schoolloopbaan-gegevens kunnen dit soort analyses echter ook op basis van werkelijke cohorten worden uitgevoerd.

\subsection{De landelijke overheid}

De landelijke overheid is, naast haar rol op het vlak van de wet- en regelgeving, ook als informatievrager betrokken. Die informatievraag hangt enerzijds samen met de uitvoering van de wet- en regelgeving, anderzijds met de wettelijke opdracht tot bewaking van de kwaliteit van het stelsel en met specifieke vragen in verband met de beleidsvoorbereiding. Zoals in hoofdstuk 2 aangegeven is het beleid erop gericht de gegevensuitwisseling tussen onderwijsinstellingen en overheid beter en meer op onderlinge afspraak te regelen (informatiestatuut, informatieparagraaf in de ontwerp-WEB) en daarbij een strikter onderscheid te maken tussen verplichte gegevenslevering in het kader van de bekostiging en aanvullende gegevenslevering ten behoeve van evaluatie en beleidsvoorbereiding ('beleidsinformatie'). Gegevens betreffende de schoolloopbaan vallen in de tweede categorie. Gegevens over de bestemming zullen door aanvullend onderzoek moeten worden geleverd; RUBS dient dus ook een landelijke informatiebehoefte.

Analyses op het verband tussen inrichtingskenmerken van het onderwijs, schoolloopbaanpatronen, extern rendement en bestemmingen kunnen aansluiten op een aantal actuele beleidsvragen: ongelijkheid van kansen (verschillen in leerweg en extern effect van leerlingen met allochtone achtergrond en van meisjes), effecten van meer en minder 'gewenste' leerwegen (omwegen-debat), effecten van de leerweg op het extern effect (b.v. effecten van kortere en langere leerwegen, effecten van vertraging), vergelijkingen tussen inrichtingsvarianten e.d. 


\section{Conclusies, aanbevelingen}

De uitgangssituatie

In de hoofdstukken 2 en 3 is een aantal conclusies geformuleerd aangaande de mogelijkheden tot een RUBS op cohortbasis en aangaande de behoefte aan informatie op basis van een dergelijk type onderzoek. In hoofdstuk 2 is vooral gekeken naar het type informatiehuishouding en het type informatiebehoefte die voortvloeien uit het voorziene nieuwe wettelijke stelsel in de BVE-sector. Ook is gekeken naar een aantal voorwaardelijke aspecten, in het bijzonder de ontwikkeling van een informatiestatuut en het leerlingnummer. Algemene conclusie is hier dat het wettelijke stelsel een grote en onvermijdbare vraag met zich meebrengt naar informatie over de arbeidsmarkteffecten in relatie tot opleidingen en specifieke groepen leerlingen. Voor een deel van deze informatie heeft analyse op cohortbasis een duidelijke toegevoegde waarde: op instellingsniveau in het kader van de interne kwaliteitszorg, op intermediair niveau in verband met taken in verband met de landelijke kwalificatiestructuur, op landelijk niveau in het kader van de monitoring van de efficiëntie van het bestel als geheel. De ontwikkeling van de nieuwe informatiehuishouding, in het bijzonder het uitgangspunt van levering van basale gegevens op leerlingniveau via een leerlingnummer, schept gunstige voorwaarden voor een RUBS op cohortbasis.

In hoofdstuk 3 is ook naar de behoefte aan informatie uit RUBS op cohortbasis gekeken, maar meer vanuit de invalshoek van de actuele en manifeste behoeften bij instellingen, intermediaire organen en overheid. Algemene conclusie was hier dat er vooral op schoolen intermediair niveau een potentieel grote maar veelal latente vraag moet worden aangesproken. Gezien de conclusies aangaande de informatiehuishouding van de scholen is het vooral voor hen van groot belang dat het betrokkenen gemakkelijk wordt gemaakt van de meerwaarde van RUBS op cohortniveau gebruik te maken. Zonder gerichte service en ondersteuning zal er op korte termijn waarschijnlijk geen optimaal gebruik van alle mogelijkheden plaatsvinden. Hetzelfde geldt tot op zekere hoogte voor de landelijke organen beroepsonderwijs, zij het dat de informatiebehoefte hier meer is gericht op de externe effecten; de toegevoegde waarde van het cohortmodel is minder pregnant. Op overheidsniveau is hier minder een probleem; hier kan ook worden aangesloten op het eerdere beleidsmatige gebruik van cohortonderzoek.

\section{Volgen of vooruitlopen?}

In dit slothoofdstuk gaat het om de beleidsmatige conclusies die aan het voorgaande kunnen worden verbonden. Tot welke uitgangspunten voor RUBS in de komende jaren leiden de aangetroffen wettelijke situatie, de behoeften en de technische mogelijkheden? In hoofdstuk 1 werden, op basis van een verkenning van recente ontwikkelingen binnen en rond RUBS, een geactualiseerde vraagstelling en een aantal desiderata en 
voorwaarden geformuleerd.

De geactualiseerde vraagstelling luidde:"

1. het verkennen van de mogelijkheden voor een RUBS-model dat longitudinale analyses op basis van entree-kenmerken, schoolloopbaangegevens en vervolgposities mogelijk maakt,

2. met optimaal gebruik van de mogelijkheden van het landelijk leerlingnummer,

3. dat aansluit op de behoeften en gebruiksmogelijkheden op school-, intermediair en landelijk niveau,

4. met bijzondere aandacht voor de nieuwe gebruiksmogelijkheden op intermediair niveau binnen het WEB-stelsel,

5. en dat past binnen het huidige budgettair kader en anticipeert op een toenemend belang van vrijwillige deelname van scholen en intermediaire organen;

6. het formuleren van de uitgangspunten voor het ontwerpen en implementeren van zo'n model."

Als desiderata werden genoemd: analyse van schoolloopbanen op instellingsniveau en efficiënt gebruik van het leerlingnummer. Als voorwaarden en criteria werden genoemd: behoud van multifunctionaliteit van RUBS, bruikbaarheid op schoolniveau, uitbreiding van functies op intermediair niveau, de nieuwe functies in de WEB en het financieel kader.

De desiderata en technische mogelijkheden enerzijds en de genoemde voorwaarden en de aangetroffen situatie in het veld anderzijds leiden niet eenduidig tot eenzelfde conclusie. Op enige punten is nadere afweging nodig. Centraal in deze afweging staat de vraag: volgen of vooruitlopen? Het is duidelijk dat er op informatie-technisch niveau een aantal mogelijkheden zijn die thans onderbenut blijven. $\mathrm{Er}$ is ook een latente vraag naar benutting van deze mogelijkheden. Anderzijds noopt de in het onderwijsveld aangetroffen situatie tot voorzichtigheid: de kloof tussen het technisch mogelijke en beleidsmatig wenselijke enerzijds en practisch haalbare anderzijds kan hier snel te groot worden.

Punten van nadere overweging zijn:

1. Landelijk steekproefkader vs. instelling als primaire eenheid. Thans vormen 'opleidingsclusters in scholen' de primaire eenheden van de steekproeftrekking (technisch werkdocument RUBS 1994). Dat betekent dat binnen de deelnemende scholen één of meer opleidingen of onderwijstypen als geheel worden meegenomen; alle uitgestroomde leerlingen hiervan worden als respondent benaderd. Op het moment dat op landelijk niveau van alle leerlingen gegevens beschikbaar zijn is het mogelijk uit het landelijk bestand een steekproef te trekken. Bij gebruik van dit zgn. landelijke steekproefkader kan een steekproef worden getrokken zonder tussenkomst van de scholen.

Er zijn wel eerder ideeën in deze richting geweest, waarbij werd gedacht aan lesgeldinningsbestand van de Informatie Beheer Groep te Groningen. Daarbij kwamen echter problemen om de hoek kijken, in het bijzonder het ontbreken van opleidingsgegevens in dit bestand. Het leerlingnummer lijkt op dit punt minder problemen op te roepen, omdat

* de registratie volledig zal zijn: door de noodzaak tot levering door de koppeling aan 
bekostigingsgegevens enerzijds en door de koppeling aan de actuele persoons- en adresgegevens in de GBA anderzijds zal het leerlingnummer-bestand in potentie een zeer bruikbaar steekproefkader zijn.

* het volgen na uitstroom veel makkelijker is, vooral door de koppeling aan de GBA. Ook na uitstroom zullen de adresgegevens worden gemuteerd, waardoor een veel hogere respons mogelijk is.

Tegenover deze veelbelovende technische mogelijkheden staan de in hoofdstuk 1 geschetste behoefte aan en noodzaak tot voortgezette en zelfs versterkte oriëntatie van RUBS op de onderwijsinstellingen. Overwegingen zijn hier:

* het geschetste belang van RUBS-gegevens, en met name ook analyses op cohortbasis, binnen het stelsel van interne kwaliteitszorg; voor het feitelijke gebruik van deze gegevens is een directe betrokkenheid van de school gewenst;

* de band die scholen hebben met hun oud-leerlingen; hoewel de meningen daarover verdeeld zijn benadrukken enige geïnterviewden het belang van deze band voor een goede respons, in vergelijking met enquêtering vanuit een anonieme landelijke organisatie;

* althans binnen het AVONWO de inpassing van RUBS in het schoolverlatersvolgsysteem, als gevolg van het zgn. integratieproject; het SVS gaat bij definitie van de school uit. Ook in de BVE-sector is het actief vanuit de school volgen en ondersteunen van oud-leerlingen zeker een mogelijkheid, bij voorbeeld met het oog op kwetsbare groepen;

* de toenemende financiële afhankelijkheid van de deelname van afzonderlijke scholen.

Deze punten overwegende lijkt er toch een voorkeur uit te gaan naar een blijvende koppeling tussen RUBS en scholen, waarbij de primaire eenheid van de steekproeftrekking het 'opleidingscluster binnen school' blijft. Het begrip 'steekproeftrekking' is daarbij erg betrekkelijk: in feite ontstaat de onderzoeksgroep door de vrijwillige deelname van de scholen en door de onderwijseenheden die zij doorgelicht wensen te zien; door weging en selectie wordt hieruit een landelijk beeld gedestilleerd. Dit model is zowel onderzoekstechnisch als financieel goed hanteerbaar zolang voldoende scholen deelnemen, en dat zal het geval zijn zolang de bruikbaarheid van de RUBS-gegevens voor de scholen en de service voldoende zijn, bij aanvaardbare prijs.

Wel zullen, als gevolg van de vrijwillige deelname, onevenwichtigheden en lacunes in de landelijke steekproef ontstaan die niet door middel van weging hersteld kunnen worden. Het zal dus altijd nodig blijven bepaalde 'witte vlekken' (naar opleiding of naar regio) te vullen door middel van aanvullende steekproeftrekking. Deze zal bij voorkeur vanuit een landelijk steekproefkader plaatsvinden. Een ander mogelijk gebruik van het landelijk steekproefkader is onderzoek naar voortijdig schoolverlaters. De scholen hebben hier weinig interesse in; ook is het benaderen van de voortijdige schoolverlaters voor hen vaak moeilijk. Vanuit het landelijk beleid is deze groep echter zeer interessant. Op basis van 
het landelijk gegevensbestand is directe benadering mogelijk, waarbij ook nog onderscheid mogelijk is tussen 'echte' schoolverlaters en overstappers naar ander onderwijs (waaronder ook niet door OC \& W bekostigde opleidingen).

2. Vermijden van afhankelijkheid van externe systemen: vooral vanuit de verantwoordelijke voor de dataverzameling binnen RUBS, DESAN, is gewaarschuwd voor de gevaren van afhankelijkheid van externe informatiediensten. Thans functioneert RUBS op basis van gegevens die enerzijds door de scholen worden geleverd, anderzijds van de respondenten worden verkregen. Daarbij is RUBS niet afhankelijk van de specifieke inrichting van de administratie van de scholen: gegevens kunnen worden ontleend aan ieder administratief pakket en terugmelding kan geschieden in het format dat de school kan verwerken. Bij overgang naar een landelijk steekproefkader wordt deze relatieve onafhankelijkheid opgegeven. RUBS is dan afhankelijk ten eerste van de condities van beschikbaarstelling van het landelijk bestand en ten tweede van mogelijke politiek ingegeven danwel technisch noodzakelijke ingrepen daarin; door de afhankelijkheid van één bestand ontstaat er bovendien kwetsbaarheid.

3. Afweging instroom- of uitstroomcohorten: cohortanalyses kunnen zowel worden uitgevoerd op instroomcohorten als op uitstroomcohorten. Aan beide typen analyses liggen verschillende typen vraagstellingen ten grondslag. Instroomcohorten, waarbij de respondenten worden gevolgd vanaf het moment van instroom (met de instroom- en leerlingkenmerken als uitgangssituatie), leveren krachtige informatie op waar het gaat om leerlinggebonden factoren die schoolloopbanen bepalen en om evaluatie van effecten van het onderwijs (inrichting, schoolloopbaanpatronen e.d.), voorzover die op leerlingniveau tot uitdrukking komen (rendement, bestemming, succes in de beroepsloopbaan e.d.).

Uitstroomcohorten, waarbij de respondenten worden gevolgd vanaf het moment van uitstroom, zijn vooral bruikbaar voor onderzoek van de arbeidsmarkt (arbeidsmarktkansen, kwalificatie-effecten e.d.). Instroomcohorten zijn hier minder bruikbaar, aangezien de leerlingen gespreid over meerdere jaren uitstromen; als gevolg van o.m. conjunctuurschommelingen variëren de arbeidsmarktomstandigheden van jaar tot jaar, terwijl deze ingeval van een uitstroomcohort constant worden gehouden. De in dit rapport geschetste nieuwe mogelijkheden zoals het leerlingnummer maken een RUBS gekoppeld aan instroomcohorten mogelijk (koppeling aan leerlingvolgsystemen), maar faciliteren ook het opnemen van RUBS in meerjarige uitstroomcohorten (m.n. gebruik van landelijke adresgegevens). Van beide mogelijkheden kan, naar gelang de informatiebehoefte en de vraagstelling, gebruik worden gemaakt. De informatiebehoeften, zoals geanalyseerd in de hoofdstukken 2 en 3, leiden ook inderdaad tot het gebruik van beide mogelijkheden. Instroomcohorten zijn grosso modo vooral van belang in het kader van de kwaliteitszorg van onderwijsinstellingen en de kwaliteitsbewaking van het onderwijsbestel; uitstroomcohorten leveren arbeidsmarktinformatie ten behoeve van o.m. intermediaire organisaties. 
Overigens is de tegenstelling tussen instroom- en uitstroomcohort betrekkelijk zodra van een administratief (100\%) gegevensbestand op basis van individuele leerlinggegevens gebruik kan worden gemaakt. Een 'cohort' kan in zo'n bestand achteraf worden gevormd door het instroommoment danwel het uitstroommoment als sleutelveld te nemen. Het gaat er dan meer om het juiste design bij de onderhavige vraagstelling te kiezen.

\section{Uitgangspunten voor verdere ontwikkeling}

Gegeven deze overwegingen en gegeven de desiderata bij de vraagstelling zouden de volgende uitgangspunten voor een nieuw RUBS-model kunnen worden geschetst.

1. Leerlingnummer als koppelnummer. Uitgangspunt blijft de steekproeftrekking op basis van onderwijseenheden binnen instellingen (wel wordt het landelijk leerlingnummerbestand gebruikt als steekproefkader voor de aanvullende steekproeftrekking in verband met 'witte vlekken' en voortijdige schoolverlaters -zie boven-). Het leerlingnummer fungeert als koppelnummer tussen enerzijds de gegevens in het leerlingvolgsysteem en de RUBS-uitkomsten, anderzijds tussen de gegevens in het landelijk bestand en de RUBS-uitkomsten. Tevens fungeert het als koppelnummer naar de landelijke adresbank, zodat op het moment van bevraging de meest actuele adresgegevens (als opgenomen in de GBA) kunnen worden gebruikt. Alternatieven bij het gebruik als koppelnummer zijn nog: de school levert een uitgangsbestand aan, waarin leerling- en schoolloopbaangegevens op leerlingnummer zijn opgenomen, danwel de school geeft toestemming hiervoor de gegevens uit het landelijk bestand te gebruiken. Dit zal later moeten worden beslist, aangezien nog niet duidelijk is welke schoolloopbaangegevens in het landelijk bestand zullen worden opgenomen. Het is dus ook nog niet duidelijk of het landelijk bestand voldoende gegevens zal bevatten om analyses op schoolloopbaan uit te voeren, danwel of de school (en evt. de respondent op het enquêteformulier) hiervoor de vereiste gegevens moet leveren; zie ook hieronder bij 3. Ook kostenaspecten zullen een rol in de afweging spelen: zowel aan het verwerken van de schoolbestanden als aan het gebruik van het landelijk bestand zullen kosten verbonden zijn.

2. Regeling van de privacy. In verband met de privacy, i.c. de Wet op de persoonsregistratie, zal exact moeten worden vastgelegd welke persoonsgebonden gegevens via de koppelnummers wel en niet aan de instellingsadministratie resp. aan het landelijk bestand worden gekoppeld. Daarbij kan het uitgangspunt worden gehandhaafd dat ook thans reeds bij de terugmelding van de individuele gegevens aan de school wordt gehanteerd: een aantal administratieve gegevens kan vrij worden gebruikt (b.v. geslacht, leeftijd, vooropleiding, opleiding), een aantal andere niet (met name prestatiegegevens in de breedste zin). Voor de koppeling van deze gegevens dient toestemming aan de respondent te worden gevraagd. Dat betekent dat een aantal analyses op het hele bestand kunnen worden uitgevoerd, terwijl andere alleen worden uitgevoerd op het 
bestand van de respondenten die toestemming hebben gegeven.

Los daarvan dienen, in een overeenkomst met de gebruikers van de gegevens, de toegestane koppelingen en het toegestane gebruik te worden vastgelegd. Voor de instellingen is dit een standaard-overeenkomst; met de landelijke overheid wordt een afzonderlijke overeenkomst aangegaan. Het gaat daarbij b.v. om de afscherming van bepaalde RUBS-uitkomsten (werkgever, beloning e.d.) van andere gebruikers van het SoFi-nummer, b.v. de belastingdienst en de uitvoeringsorganen sociale zekerheid. Dat kan b.v. door voor de koppeling niet het ruwe landelijk bestand maar een geanonimiseerd schaduwbestand te gebruiken. Het grootste deel van deze voorwaarden is nu reeds vastgelegd in het 'beheers- en gebruiksreglement RUBS' en in de standaardcontracten met scholen en derden. Deze zullen waar nodig worden aangepast.

3. Cohortanalyses als service aan de school. Gezien de in hoofdstuk 3 gesignaleerde achterstand in de informatiehuishouding van de scholen is het niet waarschijnlijk dat de scholen op eigen kracht veel zullen doen met de nieuwe mogelijkheden van RUBS op cohortbasis. Zij zullen daarin dus ondersteuning moeten krijgen, als service binnen RUBS. Dat kan in principe op twee manieren: door ondersteuning van de uitvoering van analyses op schoolniveau of door uitvoering van de analyses op landelijk niveau.

Ondersteuning op schoolniveau zou b.v. kunnen omvatten het aanleveren van programmatuur in aansluiting op de gebruikte administratieve pakketten, het aanreiken van een 'format' in de vorm van kengetallen ten behoeve van de interne kwaliteitszorg en evt. ondersteuning bij de analyses (helpdesk).

Uitvoering op landelijk niveau is op twee wijzen mogelijk. Ten eerste kunnen de analyses worden uitgevoerd op basis van een gestandariseerd uittreksel uit de schooladministratie dat de scholen aanleveren (het uitgangsbestand; zie boven bij 1); dit bestand wordt via de koppelnummers aan de RUBS-uitkomsten gerelateerd. Een aantal analyses volgens cohortmodel kan dan standaard in de RUBS-rapportage worden opgenomen. Ten tweede kunnen analyses worden uitgevoerd op basis van de schoolloopbaan-gegevens in het landelijk bestand, waarna de uitkomsten in de rapportage aan de school worden opgenomen. Zoals boven bij 1 aangegeven zal de keuze mede afhangen van de aard en omvang van de landelijk beschikbare schoolloopbaangegevens.

Alternatieven bij beide opties zijn nog: opneming in RUBS als standaardfaciliteit (zonder meerkosten) of aanbieding als extra faciliteit tegen meerkosten.

In beide opties is het van belang dat snel aansluiting wordt gezocht bij de ontwikkeling van nieuwe administratieve programmatuur, zoals deze thans in het kader van de voorziene informatiehuishouding in WEB-verband wordt voorbereid (informatieplan BVE 1995). Beide opties zijn immers afhankelijk van efficiënte aansluiting bij de schooladministratie. 
4. Landelijk bestand als controle. Het landelijk bestand op leerlingnummer kan nog enige belangrijke functies hebben. Ten eerste zijn een aantal controles mogelijk door vergelijking van onderzoeksbestand en landelijk bestand (representativiteit, dekking), ten tweede kunnen aan de hand van meerjarige gegevens in het landelijk bestand een aantal analyses worden uitgevoerd in relatie tot de vraagstelling van RUBS volgens cohortmodel. Dat geldt zeker indien bepaalde persoonsgegevens van de uitgestroomde leerlingen mogen worden gebruikt. Deze tweede mogelijkheid is echter iets voor de verdere toekomst.

5. Analyses op intermediair niveau. Op intermediair niveau zijn er in hoofdlijn twee gebruikersgroepen van belang: het LDC en de AOB's en de landelijke organen beroepsonderwijs. Het LDC en de AOB's zijn reeds gebruiker van RUBS-gegevens. Zoals in hoofdstuk 3 aangegeven brengt het LDC een aantal informatieproducten uit waarin o.m. RUBS-gegevens zijn verwerkt. Deze instellingen hebben vooral belang bij de RUBSuitkomsten in het kader van informatie ter ondersteuning van studie- en beroepskeuzevoorlichting. Behalve transversale analyses op RUBS en analyses op uitstroomcohort (kansen per opleidingstype) kunnen analyses op instroomcohort hier een belangrijke toegevoegde waarde hebben; zij kunnen een indicatie geven van de gevolgen van keuzes tussen alternatieve leerwegen. Hiertoe wordt al een aanzet gegeven met de rapportage over leertrajecten in het voortgezet onderwijs. Zodra het cohortmodel wordt uitgewerkt zouden deze mogelijkheden verder moeten worden uitgewerkt.

De landelijke organen dienen zich als nieuwe doelgroep aan; voor hen zullen nog gerichte informatieproducten dienen te worden ontwikkeld. Voor hen lijken vooral transversale analyses, analyses op uitstroomcohorten en longitudinale analyses (zie bij 6) van belang, waarbij het gaat om analyses van kansen op de arbeidsmarkt per opleiding naar sector en naar beroepsgroep (op betrekkelijk laag aggregatieniveau). Deze doelgroep profiteert niet zozeer van het cohortmodel alswel van goede dekking, een zo laag mogelijk aggregatieniveau en actualiteit, dus snelle beschikbaarheid van analyses. Voor beide gebruikersgroepen geldt dat de beoogde informatie niet alleen door RUBS maar ook door het informatiesysteem POA wordt geleverd. De integratie van de gegevens uit het nieuwe RUBS in POA behoeft dan ook van meet af aan de aandacht.

6. Ontwikkeling van meerjarig RUBS. In het kader van het integratieproject wordt RUBS opgenomen in een meerjarig schoolverlatersvolgsysteem; de andere metingen in dit SVS hebben echter alleen een functie voor de deelnemende school. Ook in het volgsysteem van STOAS fungeert RUBS als één van de meetmomenten. In aansluiting op deze ontwikkelingen is een longitudinale opzet van RUBS, waarbij de bestemming niet eenmalig maar op een reeks van meetpunten wordt onderzocht, zeker te overwegen. Dat geldt zeker ook voor de uitstroom uit het beroepsonderwijs, b.v. om de ontwikkeling van het carrièrepatroon van de gediplomeerden naar type en niveau te onderzoeken. Naar voorbeeld van het agrarisch onderwijs kan dit type onderzoek voor de hele BVE-sector 
worden ontwikkeld, zowel als landelijk aanbesteed onderzoek (b.v. meerjarig volgen van een steekproef uit de RUBS-respondenten), als op instellingsniveau, in de vorm van een extra faciliteit bij RUBS. Het SoFi-nummer maakt het mogelijk steeds over een actueel adressenbestand te beschikken, zodat de problemen die zich vroeger met dit type longitudinaal onderzoek voordeden omzeild kunnen worden. Uiteraard behoeft deelname aan dit onderzoek op deze wijze wel de instemming van de respondent.

\section{Ontwikkeltraject}

Volgens plan zullen alle leerlingen in de BVE-sector in het schooljaar 1996/97 op leerlingnummer in het schooladministratie worden opgenomen, en van daaruit in het bestand voor landelijk gebruik. Dat betekent dat een RUBS volgens cohortmodel in deze sector in 1997 van start kan; in de andere vormen van onderwijs is dat 1998. Het jaar 1996 kan dus v.w.b. BVE worden benut voor de organisatorische en methodologische voorbereiding. Hierin staat programmatuurontwikkeling centraal: voor de gegevenslevering door de scholen, voor de analyses van schoolloopbaangegevens gerelateerd aan RUBSuitkomsten (op schoolniveau en/of als landelijke service) en voor landelijke analyses. Ook het ontwikkelen van een 'format' voor het gebruik op instellingsniveau, in nauwe samenwerking met vertegenwoordigers van het onderwijsveld, is van groot belang.

Gezien de omvang van deze voorbereidende werkzaamheden lijkt aanbesteding als afzonderlijk ontwikkelingsproject zeker noodzakelijk. Daarbij dient een zwaarwegend argument te zijn dat zonder gerichte ondersteuning en externe aanbieding van diensten het gebruik van de nieuwe mogelijkheden van RUBS in ieder geval binnen het onderwijsveld niet of zeer traag op gang zal komen. Een flinke startinvestering kan zichzelf echter in relatief korte termijn terugverdienen in de vorm van bredere deelname, uitbreiding van bereik (o.m. landelijke organen) en vergroting van de effectiviteit.

\section{Literatuur}

Baarda, R, P. Smets, Gegevenswoordenboek beroeps- en volwasseneneducatie: onderdeel leerlingen en onderwijs voor OC\&W (versie 3.1), Smets+ Hover+, adviseurs voor professionele organisaties, Den Haag 1995.

CIBB, SOBB en SVO, Informatie is kracht; cursitenmonitor verssector, CIBB/SOBB/SVO, z.pl., 1995.

Lokman, I, Het interne rendement van het MAO; voorstel voor een onderzoek naar de berekening van rendementsindicatoren van het middelbaar agrarisch onderwijs, STOAS, bureau arbeidsmarktonderzoek, Wageningen 1994.

Ministerie van Onderwijs, Cultuur en Wetenschappen, directie Beroepsonderwijs en Volwassenen Educatie BVE, Beleidsagenda EB, Zoetermeer 1995.

Ministerie van Onderwijs, Cultuur en Wetenschappen, directie Beroepsonderwijs en Volwassenen Educatie BVE, Informatieplan van de directie BVE voor 1995, Zoetermeer 1994. 
Nederlandse Vereniging van Schooldecanen, Schoolverlatersvolgsysteem, Utrecht 1993.

Rutjes, H, Verslag dataverzameling RUBS 1994, DESAN, Amsterdam 1995.

Smoorenburg, M.S.M. Van, R.K.W. Van der Velden, Schoolverlaters op de arbeidsmarkt; de uitstroom en bestemming van het schooljaar 1992-1993, ROA/LDC, Leeuwarden 1995.

Smoorenburg, M.S.M. Van, R.K.W. Van der Velden, Technisch werkdocument RUBS 1994; de uitstroom en bestemming van schoolverlaters van het schooljaar 1992-1993, ROA, Maastricht 1995.

Velden, R.K.W. Van der, Discussienota 'hoe verder met RUBS', ROA, Maastricht 1994.

Vincken, J, Studentenwerving, Thema, 1994 nr. 3. 